\title{
O Problema da Classificação dos Bens na República de Platão
}

\author{
Luiz Maurício Bentim da Rocha Menezes
}

Plato's division of goods performed by Glaucon in the Republic involves three kinds of goods: the first kind would be desirable for their own sake; the second, desirable in themselves and in their consequences, and the third kind, only desirable in their consequences. The problem to understand it is thus presented: in which of these kinds is justice observed, and which one provides happiness to men. According to Socrates, justice should be placed on the second kind of good if men want to be happy. However, it is not in this way that the many (polloi) hold justice, for they include it in the third kind. Having this difference under perspective, Glaucon defends this point of view, willing afterwards to listen to Socrates' refutation of his argument and the defence of justice as being a good desirable in themselves and their consequences. The aim of our work is to present an interpretation that can justly adapt to what Glaucon understands as 'in themselves' and as a 'consequence' of the goods in this division.

\section{Introdução}

O Livro II da República se inicia com o furor de Gláucon em reacender o debate em torno da justiça. Achando que Sócrates não foi verdadeiramente persuasivo em provar que de toda maneira é melhor ser justo do que injusto [ $\dot{\omega} \varsigma \dot{\alpha} \lambda \eta \theta \tilde{\omega} \varsigma \pi \varepsilon \tilde{\tau} \sigma \alpha \iota$ ö $\tau$

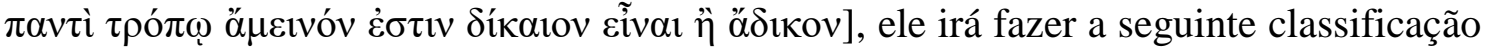
sobre os tipos de bem [ảy $\alpha \theta$ óv] ${ }^{1}$ :

(i) O primeiro tipo de bem é aquele que desejamos não por suas consequências

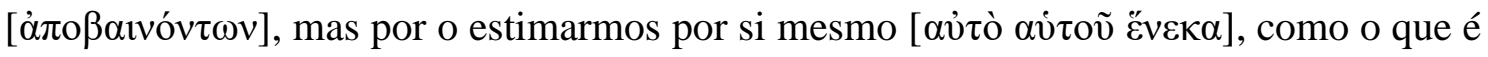

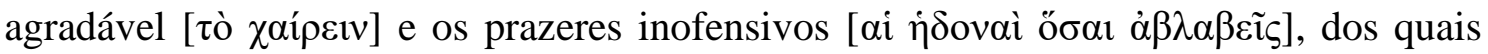

${ }^{1}$ Rep., 357b4-d2. Utilizamos aqui a tradução de Maria Helena da Rocha Pereira A República (Lisboa: Fundação Calouste Gulbenkian, 2001). Tomaremos esta tradução como base para nosso trabalho, indicando outras traduções, inclusive nossas, quando for o caso. Todas as referências à 'República' serão abreviadas por Rep. indicando-se em seguida a numeração. Para o original grego, utilizamos o texto estabelecido por S. R. Slings, Platonis Rempvblicam (Oxford: Oxford University Press, 2003). 


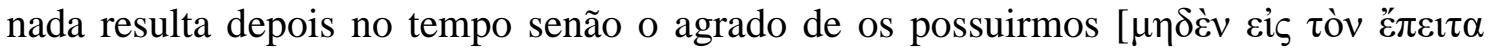

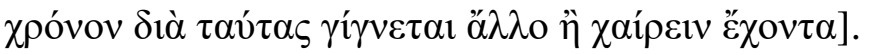

(ii) O segundo tipo de bem é aquele que gostamos por ser agradável em si

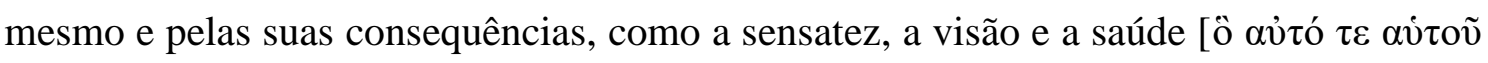

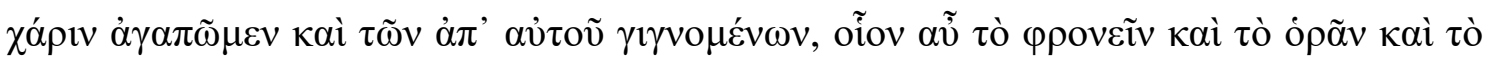
vंriaíveıv].

(iii) O terceiro tipo de bem é do tipo penoso, mas útil, e não aceitaríamos a sua posse por amor a ele, mas sim devido às recompensas e a outras consequências que dele

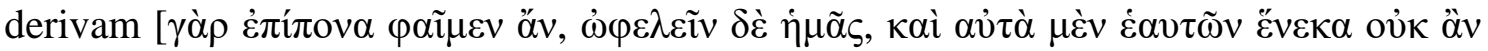

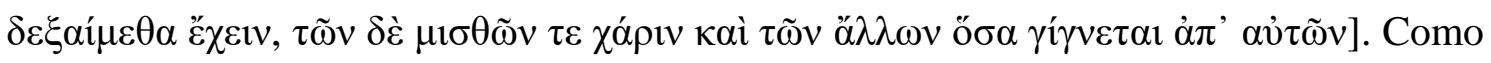
exemplos deste, temos a ginástica, o tratamento de doenças, a prática médica e outras maneiras de se obter dinheiro.

Entendemos que a tripartição dos bens implica uma diferença entre estes, mas tal diferença não está clara em sua divisão e muito estudiosos de Platão tentam interpretá-la para esclarecer o que se quer dizer com tal classificação. Alguns comentadores tentam responder a questão em termos modernos entre o que é bom por si mesmo e o que é bom por suas consequências, outros pensam que o contraste da bifurcação não é a visão moderna, mas alguma outra distinção nos termos platônicos. O primeiro tipo de bem é aquele que se expressa pelo tempo presente e é bom pelo prazer que oferece naquele momento sem nenhuma consequência futura. $\mathrm{O}$ terceiro tipo de bem é penoso, não valendo a pena por si mesmo, mas somente pelas recompensas e consequências advindas deste. O que é agradável e o que é penoso opõem-se nestes tipos de bem. O segundo tipo de bem é aquele que engloba o agradável e as consequências benéficas advindas dele, e será neste tipo que Sócrates irá colocar a justiça, pois, segundo ele, esta se encontra "no mais belo [tipo], que se deve estimar por si mesmo e pelas

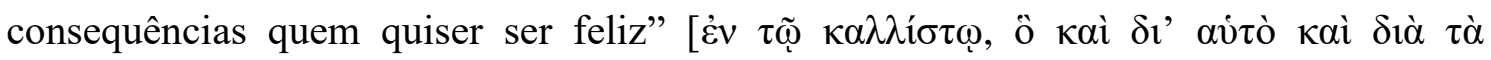

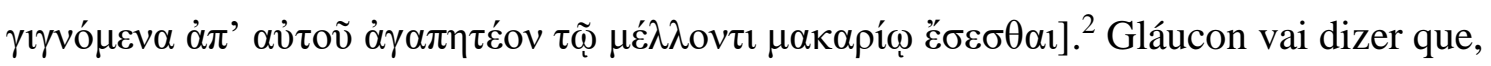

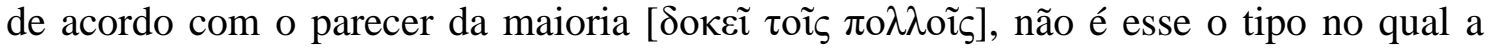

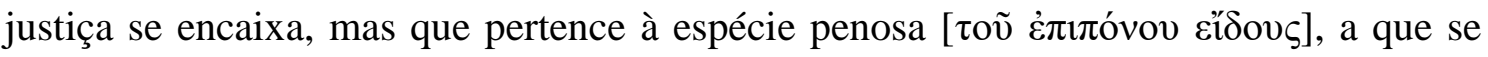
pratica por causa das recompensas, da reputação e das aparências, mas que por si

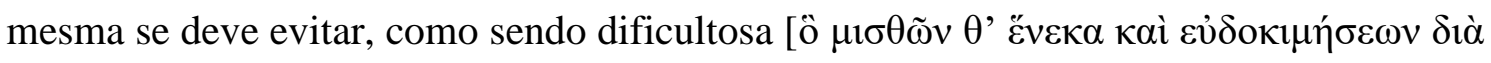

\footnotetext{
${ }^{2}$ Rep., 358a1-3.
} 


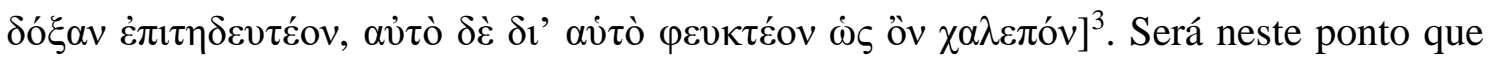
Gláucon lançará seu desafio:

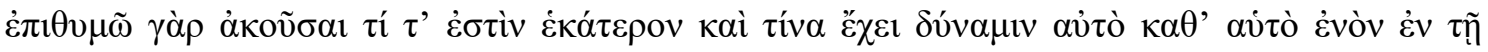

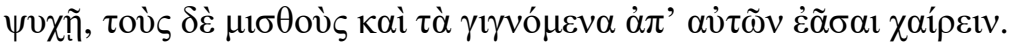

Desejo ouvir o que é cada uma delas [justiça e injustiça], e que capacidade possui por si, quando existe na alma, sem ligar importância a recompensas nem a consequências agradáveis. ${ }^{4}$

Ao dizer que o segundo tipo é estimado por aqueles que desejam ser felizes, Sócrates parece indicar que o que está em jogo na classificação dos bens de Gláucon é que tipo de relação estes bens estabelecem com a felicidade. Em resposta a Sócrates, Gláucon irá dizer que os polloi não pensam que a justiça possa ser boa por si mesma, pois acreditam que ela só é boa por suas consequências. Para responder ao desafio de Gláucon, Sócrates primeiramente deve provar o que são a justiça e a injustiça e que

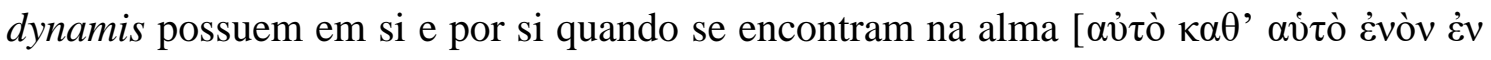
$\tau \tilde{n} \psi v \chi \chi \tilde{n}]$, sem dar importância a recompensas nem a consequências; só assim Sócrates poderá demonstrar que a justiça se encontra no segundo tipo de bem e não no terceiro, sendo ela desejada por aqueles que querem ser felizes. Tanto Sócrates quanto os polloi concordam que a justiça possui consequências desejadas (mesmo que estas não sejam as mesmas), mas divergem quanto o resto, pois para Sócrates a justiça é boa por si mesma e para os polloi, não. Acordados quanto às suas consequências, deve Sócrates primeiramente defender que a justiça é boa por si mesma. O problema, resumidamente, consiste em saber o que Gláucon entende por 'bem por si mesmo' e 'bem por suas consequências', se Sócrates prova ou não prova que a justiça é boa por si mesma, se ela pertence ao segundo tipo de bem e que tipo de relação a felicidade estabelece com a justiça. ${ }^{5}$ Para melhor entendermos o desafio proposto, devemos primeiro analisar o que Gláucon quer dizer com ‘bem por si mesmo' e 'bem por suas consequências'.

\footnotetext{
${ }^{3}$ Rep., 358a4-6.

${ }^{4}$ Rep., 358b4-7.

${ }^{5}$ Consideráveis estudiosos sobre a questão da classificação dos bens são: Foster, M. B. A Mistake of Plato's in the Republic. Mind, v. 46, n. 183, 1937, p. 386-393 e Mistake of Plato's in the Republic: A Rejoinder to Mr. Mabbott. Mind, v. 47, n. 186, 1938, p. 226-232; Mabbott, J. D. Is Plato's Republic Utilitarian? Mind, v. 46, n. 184, 1937, p. 468-474; Sachs, D. A Fallacy in Plato's Republic. PhR, v. 72, n. 2, 1963, p. 141-158, reimpresso in Vlastos, G. (ed.), Plato 2. Notre Dame, Indiana: University of Notre Dame Press, 1978, p. 35-51 (citações seguem a última paginação); Kirwan, C. Glaucon's Challenge. Phronesis, v. 10, n. 2, 1965, p. 162-173; White, N. The Classification of Goods in Plato's Republic. JHPh., v. 22, n. 4, 1984, p. 393-421; Irwin, T. H. Republic 2: Questions about Justice. In: Fine, Gail. Plato2. New York; Oxford: Oxford University Press, 1999, p. 164-185. Heinaman, R. Plato's Division of Goods in the
} 
A compreensão da tripartição dos bens se faz necessária para entendermos o alcance do desafio proposto. Há uma longa discussão entre os comentadores da passagem sobre o que, de fato, Gláucon está entendendo por 'em si mesmo' e por 'consequências'. Gláucon por bem em si mesmo quer ver demonstrado os efeitos que tanto a justiça como a injustiça provocam na $\mathrm{alma}^{6}$, o que faria com que as consequências fossem tomadas como algo que não se produz causalmente pelo bem, mas que pode ser dele retirado como as recompensas (misthoi) e a aparência (doxa). Nos bens de terceiro tipo, percebemos que eles são considerados úteis e penosos, tendo somente as suas consequências como aprazíveis. No entanto, ao analisarmos seus exemplos, isto é, a ginástica, tratamento de doenças e a prática médica em geral, percebemos que há benefícios causais que não podem ser retirados. Por benefícios causais entendemos o 'por si mesmo' do bem. Por exemplo, ao se fazer ginástica não podemos dizer que a sua utilidade não seja um benefício causal, como tornar o corpo saudável ou mais forte, por exemplo. Desse modo, a utilidade advinda de um bem de terceiro tipo não está ligada às suas consequências, mas aos benefícios causais desse bem. Do mesmo modo poderíamos falar da prática médica ou de qualquer outra arte que se encontre em um bem de terceiro tipo, pois toda arte continua sendo útil e benéfica independente das consequências avindas dos misthoi. ${ }^{7}$ Se aquilo que é útil em um bem está relacionado ao seu 'em si mesmo', então poderíamos inferir que todos os bens seriam úteis por princípio e não por suas consequências. Dessa forma, o que compreendemos como 'por si mesmo' está relacionado a todo tipo de benefício causal, como a utilidade, por exemplo; o que compreendemos por 'consequências' tem relação com os misthoi e/ou a doxa, podendo ser retirado do bem.

Falando da diferença entre bens de segundo tipo e bens de terceiro tipo, eles se dividiriam assim:

- Bens de $2^{\circ}$ tipo: são úteis e agradáveis em si mesmos e possuem boas consequências.

- Bens de $3^{\circ}$ tipo: são úteis e penosos em si mesmos e possuem boas consequências.

Republic. Phronesis, v. 47, n. 4, 2002, p. 309-335. Reeve, C.D.C. Philosopher-Kings. The Argument of Plato's Republic. Indianópolis; Cambridge: Hackett Publishing Company, Inc., 2006, p. 24-33 e Glaucon's Challenge and Thrasymacheanism. Oxford Studies in Ancient Philosophy, v. 34, p. 69-103, 2008; Payne, A. The Division of Goods and Praising Justice for itself in Republic II. Phronesis, v. 56, p. 58-78, 2011.

${ }^{6}$ Rep., 358b4-7.

${ }^{7}$ Cf. Rep., 346a1-e2. 
A diferença é muito sutil, mas consiste em uma diferença entre agradável ( $2^{\circ}$ tipo) e penoso ( $3^{\circ}$ tipo). Ambos os bens de $2^{\circ}$ tipo e $3^{\circ}$ tipo são úteis em si mesmo, ou seja, possuem benefícios causais. Isso se deve a um problema existente nos bens de $3^{\circ}$ tipo, cujos exemplos são a ginástica, o tratamento de doenças e a prática médica ${ }^{8}$ (e, talvez, inferindo daí todas as demais artes). ${ }^{9}$ Os bens de terceiro tipo possuem utilidade em si mesmos. O exemplo da ginástica é o mais claro: aquele que pratica ginástica não adquire a sua utilidade devido aos misthoi, mas de maneira causal (em si mesmo). Todos os que praticam a ginástica terão essa utilidade como algo em si mesmo do bem em questão. Ou seja, não é possível retirar a utilidade dos bens de terceiro tipo, como é possível retirar os misthoi desses bens. Se não é possível retirar a utilidade do bem, então a utilidade dos bens de terceiro tipo não pode ser um misthos. Dessa forma, a diferença específica entre os bens de $2^{\circ}$ tipo e os bens de $3^{\circ}$ tipo consiste em que os bens de $2^{\circ}$ tipo são agradáveis e os bens de $3^{\circ}$ tipo são penosos.

Para que isso fique claro em nosso trabalho, iremos, primeiramente, expor o estado da arte através da análise crítica dos principais comentadores da passagem sobre a tripartição dos bens na República. Posteriormente, iremos apresentar uma interpretação que possa adequar corretamente o que Gláucon entende como 'em si' e como 'consequência' dos bens em sua classificação.

\section{Status Quaestionis}

Foster é um dos primeiros a discutir a dificuldade dos bens. Ele diz que o Livro II se inicia com uma falsa declaração na passagem 357a1-358a9, onde é pedido a Sócrates que prove ser a justiça um bem de segundo tipo, contrário aos seus oponentes, que a colocam no terceiro tipo de bem. Para ele, esta seria a demanda original de Gláucon feita a Sócrates, no entanto, segundo o que diz, tal demanda discutida na passagem não é argumentada na República e nem é a questão que Gláucon e Adimanto têm a intenção de propor para o argumento. ${ }^{10}$ Segundo pensa, a defesa de Sócrates da

\footnotetext{
${ }^{8}$ Rep., 357c6-7.

${ }^{9}$ Por demais artes, tomamos todas as artes manuais que parecem ser do tipo penoso, apesar de apresentarem uma utilidade em si mesma. Dessa maneira, o trabalho do carpinteiro, do ferreiro ou do sapateiro poderia ser entendido como um trabalho penoso, cujos benefícios causais, i. e., a utilidade, de seu trabalho são independentes dos misthoi adquiridos no exercício da sua função.

${ }^{10}$ Foster, op. cit., 1937, p. 386.
} 
justiça consiste na demonstração de que a felicidade é consequência natural da justiça e em nenhum lugar Sócrates argumenta que a justiça pode ser um bem se não atende por essa consequência ${ }^{11}$. Assim, a proposta teria sido modificada, pois tanto Gláucon como Adimanto querem saber os benefícios da justiça ou, em outros termos, quais suas consequências naturais e não, como originalmente se disse, o que é a justiça em si mesma. Foster pensa que a demanda original proposta por Gláucon difere do que ele diz em $358 \mathrm{~b}$ onde este quer ouvir as consequências que são naturalmente procedidas da justiça e não aquelas consequências obtidas por parecer justo, entendendo que a

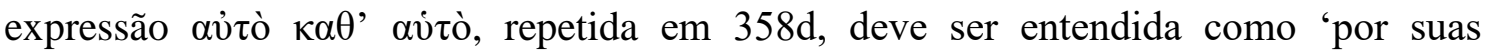
próprias consequências e à parte das adquiridas por sua reputação' ${ }^{12}$, pois o que se quer ver elogiado é o que é produzido diretamente da justiça e não os misthoi e a doxa, já que estes seriam elementos artificiais que podem ser obtidos por quem possui a aparência de merecê-los, o que não acontece com as consequências naturais. ${ }^{13}$

Outro ponto levantado por Foster seria que, segundo o seu entendimento, Platão utiliza dois tipos de expressão para significar a mesma tarefa de Sócrates na República entre 357a e 612a, sendo estas expressões:

(i) que ele deve demonstrar que a justiça é boa por si mesma e à parte de suas consequências.

(ii) que ele deve demonstrar que a justiça tem boas consequências para o homem que a possui e que isto o beneficia.

Para Foster, Platão, mesmo se expressando de duas maneiras diferentes, deseja uma única coisa que é provar que a justiça vale a pena, mesmo não contando com suas recompensas convencionais por causa da felicidade que é sua consequência necessária, mas ele é culpado dessa ambiguidade verbal ao utilizar duas expressões diferentes para dizer a mesma coisa ${ }^{14}$, pois, de acordo com a sua interpretação, a justiça ter boas consequências naturais é o mesmo que ela ser boa por si mesma.

Dessa forma, a discussão gira em torno do que são as consequências naturais da justiça ou aquilo que vem diretamente de um bem, e suas consequências artificiais, se existirem, sendo estas os misthoi e a doxa, e não entre 'por si mesmo' e 'por suas

\footnotetext{
${ }^{11}$ Ibid., p. 386-7.

${ }^{12}$ Ibid., p. 389.

${ }^{13}$ Ibid., p. 387.

${ }^{14}$ Foster, op. cit., 1938, p. 229.
} 
consequências'. Isso por si próprio seria uma solução para a consistência da passagem, se não fosse por outro problema. Ao examinar o terceiro tipo de bem, Foster irá considerar que os misthoi aqui estão fora de lugar, pois a ginástica e o tratamento médico não são desejados apenas por seus misthoi, pois possuem, por si mesmos, consequências naturais como a saúde, por exemplo, que naturalmente pode vir da prática da ginástica ou do tratamento médico, independente se estes receberão misthoi ou não. Parece que a própria terminologia encontrada por Foster para classificar os bens não funciona com os bens de terceiro tipo. A confusão se torna ainda maior quando Foster analisa o que Adimanto diz em 367c-d:

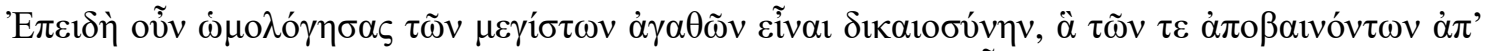

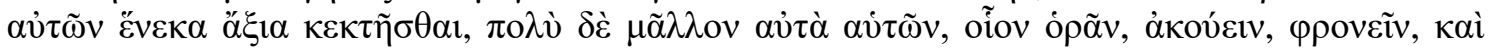

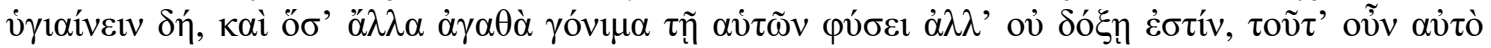

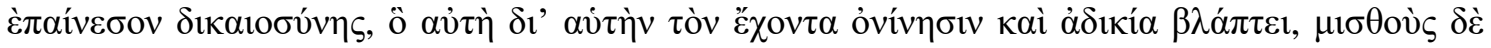

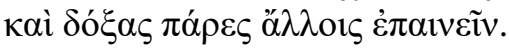

Uma vez, pois, que concordaste que a justiça figura entre os maiores bens, os que são dignos de se possuírem em virtude das consequências que deles derivam, mas muito mais ainda por eles mesmos - tais como a visão, a audição, a sensatez, a saúde, e quantos outros bens há aí produtivos pela própria natureza, e não resultantes da reputação - exalta então na justiça o que ela tem de vantajoso por si mesma para quem a possui e, na injustiça, o que ela tem de prejudicial, deixando a outros o cuidado de elogiar as recompensas e a reputação. ${ }^{15}$

Para ele, a primeira parte da sentença (367c6-8) implica que a questão é se a justiça é elogiada por si mesma ou por suas consequências, mas a segunda parte (367c9d3) é se ela é elogiada pelas suas consequências naturais ou pelos misthoi e pela doxa. Por esses motivos considera a passagem 357a1-358a9, que inclui toda a classificação dos bens, como sendo um erro, e que se fosse retirada resolveria o problema da inconsistência desta passagem com o resto da República.

A interpretação de Foster leva em consideração a terminologia moderna para consequência, mas não para o 'em si mesmo'. Apesar de ele considerar que Sócrates não responde o 'por si mesmo’ da justiça, ele interpreta que, na verdade, o que Sócrates toma como 'por si mesmo' é a consequência natural, que não pode ser da justiça retirada. Dessa forma, teríamos, na verdade, dois tipos de consequências: natural e artificial. O problema da divisão de Foster é que o terceiro tipo de bem também apresenta consequências naturais, o que não permite a correção por ele feita.

\footnotetext{
${ }^{15}$ Rep., 367c-d.
} 
Em sentido contrário a Foster, Mabbott acredita que Platão supõe demonstrar tanto que a justiça é boa por si mesma e que é boa por suas consequências. ${ }^{16}$ Para ele, é estranha a interpretação de Foster de $\alpha$ đò $\kappa \alpha \theta$ ' $\alpha$ iò̀ como sendo 'por suas próprias consequências e à parte das adquiridas por sua reputação, ${ }^{17}$, e que a demanda original feita a Sócrates é demonstrar que a justiça é boa por si mesma e por suas consequências tendo Gláucon como oponente que tem como ponto de vista a justiça como não sendo boa, mas necessária. ${ }^{18}$ No desafio de $358 \mathrm{~b}$, diz que a rejeição de Gláucon não é apenas aos misthoi e a doxa, mas também às consequências [ $\tau \grave{\alpha} \gamma l \gamma v o ́ \mu \varepsilon v \alpha \alpha \dot{\alpha} \pi$ ' $\alpha$ $\tau \tilde{\omega} v$ ] e, por

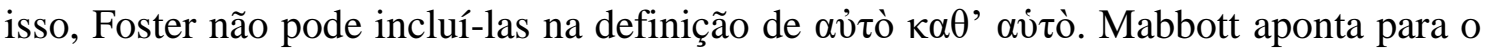
paralelismo entre saúde e justiça no Livro $\mathrm{IV}^{19}$, onde a saúde aparece como sendo naturalmente boa para o corpo assim como a justiça para a alma, e lembra, com isso, que a saúde é um bem de segundo tipo, demonstrando que Platão nunca esqueceu a promessa de colocar a justiça no melhor tipo de bem. ${ }^{20}$ Segundo ele, a justiça de Platão significa uma condição da alma e a ação é meramente sua expressão natural. ${ }^{21}$ Apesar de sua defesa de que Sócrates deve provar (a) que a justiça é boa por si mesma e (b) que ela é boa por suas consequências, (a) é uma tarefa sem esperança, pois para se provar que alguma coisa é boa por si mesma é dar uma razão do porquê ela é boa, o que já é uma admissão de que ela não é boa por si mesma, pois, para ele, qualquer um que acredite que alguma coisa é boa por si mesma não pode argumentar, mas somente afirmar ou testemunhar. ${ }^{22}$

O que Mabbott tentou em sua interpretação foi demonstrar a classificação em termos modernos, dividindo-a entre bens por si mesmo e bens por suas consequências. Admitindo que Sócrates demonstra no Livro IX as consequências da justiça, ele tentará mostrar-nos que Sócrates também demonstra a justiça por si mesma. No entanto, ao tentar demonstrar isto fora dos termos platônicos, acaba que ele mesmo se coloca em situação de dificuldade, ao não conseguir, nos seus termos, definir que a justiça é boa por si mesma, já que considera isso uma tarefa sem esperança, pois para se provar que

\footnotetext{
${ }^{16}$ Mabbott, op. cit., p. 469.

${ }^{17}$ Ibid., p. 470.

${ }^{18}$ Ibid., p. 471.

${ }^{19}$ Rep., 444d-445b.

${ }^{20}$ Mabbott, op. cit., p. 473.

${ }^{21}$ Ibid., p. 474.

${ }^{22}$ Ibid., p. 474.
} 
alguma coisa é boa por si mesma é dar uma razão porque ela é boa. Também não nos parece que pela simplicidade da analogia saúde para o corpo assim como justiça para a alma possa resolver o problema de se definir em Platão o que vem a ser um bem por si mesmo, mesmo que tal analogia seja encontrada no próprio Platão, pois o contexto é outro e não parece explicar uma coisa noutra.

Já a posição de Irwin de uma tese comparativa da justiça pressupõe uma divisão da felicidade em partes, tomando-se a justiça como uma parte maior da felicidade. Ele supõe que Platão não usa a 'justiça por si mesma' para incluir algumas consequências causais da justiça, aquelas que podem ser consideradas como consequências inevitáveis da justiça ela mesma, por oposição as consequências da justiça que são causalmente independentes dela. ${ }^{23}$ Dessa forma, para Irwin, a posição de Platão é consistente se ele tomar a justiça como sendo idêntica à felicidade ou uma parte desta. Para isso, irá dividir os bens entre os que são instrumentais, aqueles que são úteis pelas suas consequências circunstanciais, e os bens não-instrumentais, que são bons à parte de suas consequências. Para ele, a demanda original não é simplesmente provar que a justiça é um bem de segundo tipo, mas que Gláucon também quer ver demonstrado que de

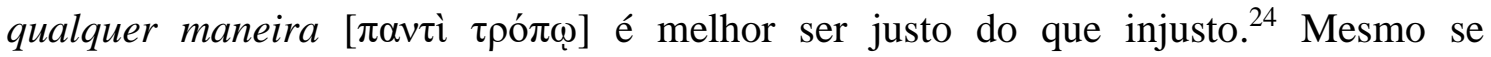
pudéssemos considerá-la adequada, ela não encontra respaldo no texto, pois a felicidade não se encontra dividida em partes, e nem a justiça aparece como sendo um componente desta. O exemplo que o autor dá do martelo não parece ser suficiente para defender uma justiça não-instrumental. Se algo parece um martelo por suas consequências, então deve assegurar todas as consequências do martelo, do contrário, se estas consequências não pudessem existir fora do martelo, seriam naturais ao martelo e, portanto, por si mesmas dele. Ao contrário do que diz Irwin, não temos uma boa razão para preferirmos um martelo genuíno a um martelo aparente devido as suas consequências. Para que o uso do martelo seja assegurado sobre qualquer outra escolha, suas consequências devem ser inerentes a este. Daí a confusão de Irwin em dividir os bens em instrumentais e nãoinstrumentais, pois ao tomar os bens instrumentais concluiu que estes possuíam consequências únicas. No entanto, a premissa que Gláucon levanta é que algo que só é louvado por suas consequências não é louvado por si mesmo e, dessa maneira, pode ser

\footnotetext{
${ }^{23}$ Irwin, op. cit., 167.

${ }^{24}$ Ibid., p. 174-175. A passagem da República é a 357b1.
} 
substituído por alguma coisa que se aparente com ele, pois se utiliza das consequências deste.

Reeve irá fazer a distinção diádica entre o que se quer por si mesmo e o que se quer por suas apobainonta, entendendo estas como sendo as consequências de Gláucon ou G-consequências como ele irá chamá-las ${ }^{25}$. Feita esta distinção, Reeve irá fazer duas importantes considerações. Primeiro que reputação e recompensas, que são $G$ consequências da justiça, não são $G$-consequências da injustiça; e em segundo lugar, felicidade não é tratada inteiramente como uma $G$-consequência, pois quando o justo e o injusto são despidos de suas G-consequências, Gláucon ainda considera possível perguntar qual deles é o mais feliz. ${ }^{26}$ Seguindo esta linha de raciocínio, Reeve não considera que as G-consequências sejam o mesmo que consequências artificiais, que são aquelas cuja honra depende da crença e atitude de outras pessoas. Segundo ele, Gláucon exclui G-consequências tanto da justiça como da injustiça, mas ele não exclui as consequências artificiais da injustiça. ${ }^{27}$ Podemos assim dizer que as G-consequências são aquelas que podem ser "retiradas", não estabelecendo uma ligação causal direta com o objeto que se refere.

Para Sachs, a posição de Foster é correta ao dizer que Platão não tentou provar que a justiça é boa em si mesma ou por si mesma no mesmo sentido que estas qualificações carregam no sentido moderno. ${ }^{28}$ Segundo ele é necessário um exame de contexto para retirar a perplexidade dos leitores contemporâneos a estas expressões utilizadas por Platão. Ao analisarmos o primeiro tipo de bem, Sachs sugere que o

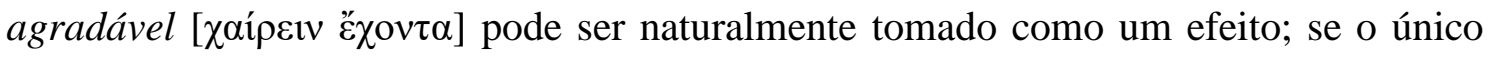
efeito de alguma coisa é o prazer ou agradável, este poderia ser um exemplo do primeiro tipo de bem. ${ }^{29}$ De acordo com os polloi, a justiça em si mesma, desde que é penosa e difícil, deveria ser evitada. Mas o penoso e o difícil desta são incluídos no 'em si mesmo'. Por analogia, a felicidade a qual Sócrates pensa que a justiça produz também

\footnotetext{
${ }^{25}$ Reeve, op. cit., p. 24. Em Reeve, 2008, p. 78; ele irá chamar estas de consequências simuladoras-acessíveis.

${ }^{26}$ Ibid., p. 28. Reeve baseia seus argumentos no terceiro argumento de Gláucon (360d8-362c6) como veremos mais a frente nesse trabalho.

${ }^{27}$ Ibid., n. 25, p. 283-4.

${ }^{28}$ Sachs, op. cit., p. 39, n. 9.

${ }^{29}$ Ibid., p. 39-40.
} 
poderia ser colocada da mesma forma. ${ }^{30}$ Gláucon ao querer saber que tipo de dynamis a justiça e a injustiça exercem por si mesmas quando presentes na alma, deixando de lado as recompensas e os efeitos de ambas, quer saber que tipo de efeito a justiça e a injustiça por si mesmas exercem na alma de seu possuidor: a felicidade ou a pena. ${ }^{31}$ Por isso, irá refazer a classificação dos bens de Gláucon da seguinte maneira: primeiro, itens que por si mesmos são geradores do bem e nada mais; segundo, aqueles que por si mesmos são geradores do bem e, em conjunto com outras coisas, têm bons efeitos adicionais; terceiro, aqueles que por si mesmos tem efeitos ruins, embora tenham alguns bons que compensam estes. ${ }^{32}$

Sachs entende que a ambiguidade verbal apontada por Foster $^{33}$ poderia ser desfeita, pois este coloca no discurso de Gláucon um possível anacronismo interpretativo do 'bem por si mesmo' e 'bem em si mesmo' como frases que marcam um contraste com as coisas boas por suas consequências, mesmo quando estes bens têm como produto a felicidade e o prazer. Para Sachs não existe tal contraste e este seria fruto de uma interpretação moderna e indevida para o texto ${ }^{34}$, pois segundo diz, a noção dos efeitos da dynamis da justiça e da injustiça nas almas dos homens é fundamental para a concepção platônica de justiça. ${ }^{35}$ Sócrates deve provar que a justiça exerce seu poder pela mera existência na alma, e a injustiça é um mal para a alma quando presente, demonstrando que aquele que possui a justiça na alma é mais feliz que qualquer um que possua a injustiça. ${ }^{36}$ No Livro IV, Sócrates diz haver apenas uma forma de arete da alma, mas ilimitadas de $k a k i a^{37}$, ressaltando quatro em especial, relativas às constituições que originam: a timocracia, a oligarquia, a democracia e a tirania. Segundo Sachs, Platão supõe que a justiça ou a injustiça, mas não as duas, devem existir em toda alma, e que o homem que tem na alma a justiça é mais feliz que o homem que inclui qualquer grau da injustiça, variando a felicidade inversamente com a injustiça. ${ }^{38}$

\footnotetext{
${ }^{30}$ Ibid., p. 40.

${ }^{31}$ Ibid., p. 41.

${ }^{32}$ Ibid., p. 41.

${ }^{33}$ Cf. Foster, op. cit., p. 229.

${ }^{34}$ Sachs, op. cit., p. 41, n. 14.

${ }^{35}$ Ibid., p. 41-2.

${ }^{36}$ Ibid., p. 42.

${ }^{37}$ Rep., 445c-d; 449a.

${ }^{38}$ Sachs, op. cit., p. 45.
} 
A visão de Sachs relativa aos bens é interessante e possui pontos que contribuem para o esclarecimento da questão. Sua posição contra uma interpretação moderna dos bens e a favor de uma visão platônica dos efeitos da dynamis na alma permite que a ambiguidade dos termos usados por Platão para se referir aos bens por si mesmos seja desfeita. No entanto, nos perguntamos que tipo de variação seria esta que acontece na felicidade que é inversamente proporcional aos graus de injustiça. Se for provado que só o justo pode ser feliz, então não poderemos separar um do outro. Dessa maneira, não podemos dividir a felicidade em graus inversos ao da injustiça, pois isso também suporia graus de justiça, o que não podemos admitir, já que só há uma forma de justiça na alma. Se a felicidade e a justiça são inseparáveis, então admitir graus de felicidade seria colocar a justiça nos demais tipos de almas e, assim, coabitar justiça e injustiça numa mesma alma, o que, mesmo que seja em graus, não é viável e nem aceito por Platão. Talvez pudéssemos aceitar por completo a explicação de Sachs se admitíssemos um engano de sua parte ao dividir a injustiça em graus ou se esta fosse dividida em graus sem supor graus de felicidade.

De acordo com Kirwan, se elogiar a justiça por si mesma inclui elogiar esta por suas consequências que fazem homens felizes, Gláucon deve fazer uma distinção entre diferentes tipos de consequência: algumas devem ser excluídas outras não. ${ }^{39}$ Kirwan acredita que a interpretação do desafio pela distinção de Foster entre consequências naturais e artificiais é errada. Para ele, um indicativo de que Foster está errado em supor que a classificação dos bens não faz parte da exposição é a ênfase que ele faz dos misthoi para o argumento, ocultando que Gláucon está realmente interessado com sua classificação em ver demonstrado que a justiça é agradável, e não epiponon. Apesar de concordar que Platão não é claro em sua distinção, ele crê que nada que Gláucon e Adimanto tenham dito depois obriga-os a retratarem a forma do desafio implicado pela tripartição dos bens: a justiça é comumente pensada como um bem penoso, cabe demonstrar que ela é agradável. A interpretação de Kirwan parece correta ao colocar em foco o problema do agradável e desagradável ao tratar dos bens. No entanto, parece um tanto estranha sua colocação quanto ao argumento de Adimanto. Na passagem 367d2,

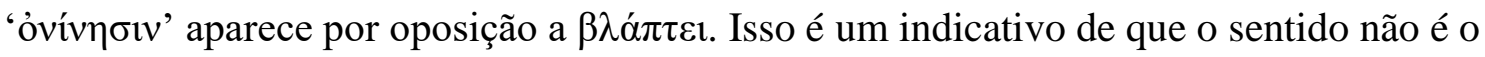

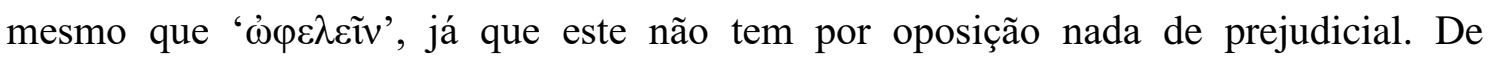
qualquer maneira, esse tipo de comparação nos parece descabida, pois, não é porque um

\footnotetext{
${ }^{39}$ Kirwan, op. cit., p. 163.
} 


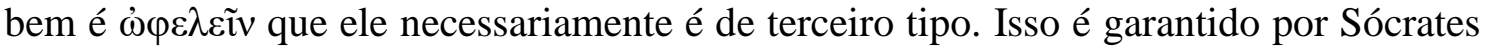

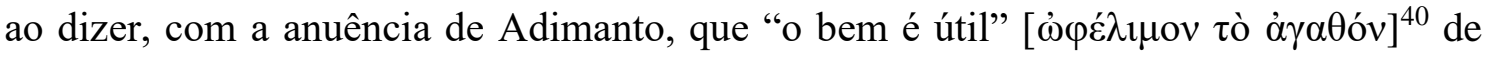
maneira geral, ao que parece, sem que isto signifique um tipo de bem específico. A nosso ver, isso permite uma maior flexibilidade de $\dot{\varphi} \varepsilon \varepsilon \lambda \varepsilon \tilde{v}$, não estando o termo, ao tratar do bem, diretamente ligado aos bens de terceiro tipo. Portanto, não há como o uso dos termos impedir a justiça de ser útil e agradável ao mesmo tempo. Quanto à relação de causa formal que Kirwan estabelece entre a felicidade e o agradável para que, ao se elogiar a justiça pela felicidade, se possa dizer que a justiça é agradável por si mesma, parece pouco conclusiva quanto o tipo de relação que a justiça estabelece com a felicidade.

Para White, a suposição de que Platão está operando com uma noção de consequência causal moderna deve ser examinada, pois pode ser falsa no sentido de que materialmente afeta a interpretação da República, incluindo o problema de reconciliar a passagem 357a-358a com o presente argumento. Por isso, o autor sugere a comparação da linguagem utilizada com outras noções causais em Platão. ${ }^{41}$ Segundo White, quando Platão alega que a justiça é boa por si mesma, muito de sua linguagem parece, em princípio, explicitamente causal, e não há razão para tomar a linguagem como um uso inadvertido. Esta linguagem causal corresponde à linguagem que ele usa quando trata sua noção de causa ou aition. ${ }^{42}$ Esta noção de aition se encaixa com o que ele tem para dizer na República sobre a conexão entre a justiça e a felicidade. Seguindo a linha de pensamento de Sachs, White dirá que quando Platão diz que a justiça é boa por si mesma, ele tem em mente a ideia de que a justiça, em certo sentido por si mesma e sem outros fatores, faz o seu possuidor ser feliz, no sentido de causa platônica. Os termos que são usualmente traduzidos por "consequências" na República 357a-358a não são termos regulares para consequência causal, tanto no grego como no uso platônico, e suas funções aqui não podem indicar a bondade de uma consequência causal em contraste à bondade intrínseca. White assim aponta, em primeiro lugar, para uma questão terminológica, onde Platão não teria, de fato, utilizado a noção de alguma coisa que é boa por si mesma ou alguma coisa que é boa por suas consequências. A distinção que Platão usa, segundo White, seria entre bens que são bem-vindos (aspazesthai),

\footnotetext{
${ }^{40}$ Rep., $379 \mathrm{~b} 11$.

${ }^{41}$ White, op. cit., p. 394.

${ }^{42}$ Para desenvolver este tipo de argumento, White irá seguir o artigo de Vlastos, G. Reasons and Causes in the Phaedo. The Philosophical Review, v. 78, n. 3, 1969, p. 291-325.
} 
louvados (agapan) ou aceitos (dexasthai ekhein) por alguma coisa ou outra. Dessa forma, avisa que usará as expressões 'bem por si mesmo' e 'bem por suas consequências', em seu trabalho, como maneiras de dizer ${ }^{43}$, o que o levará a dividir os bens da seguinte maneira ${ }^{44}$ :

(a) bens que são bem-vindos por si mesmos, não por suas consequências.

(b) bens que são bem-vindos por si mesmos e por suas consequências.

(c) bens que não poderiam ser escolhidos por si mesmos, mas somente por suas consequências.

Quando não se interpreta pelo anacronismo da distinção moderna entre bens por si mesmos e bens por suas consequências, mas, ao invés disso, se vê a relevância das noções causais que poderia se esperar que Platão usasse, então, o que ele está argumentando sobre a justiça é, nos termos platônicos, primeiro, que atuar por si mesma, pelas suas próprias capacidades causa felicidade na alma de seu possuidor e é bem-vinda por esta razão; e segundo, que agir em conjunto com certas circunstâncias circundantes produz certas outras coisas que são também bem-vindas. ${ }^{45}$ Para melhor esclarecer o uso de uma linguagem causal na descrição de Platão da relação entre a justiça e a felicidade, White irá selecionar passagens da República que parecem comprovar o que ele diz, das quais selecionamos aquelas que se encontram no Livro II:

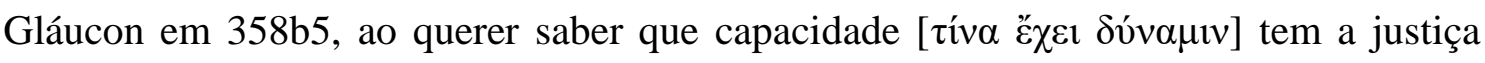
'por si mesma' na alma e 360d1, ao querer saber se a justiça é mais vantajosa [ $\lambda v \sigma ı \varepsilon \varepsilon \lambda \varepsilon i ̃ v]$ que a injustiça; Adimanto em 366e5-6, ao querer saber que capacidade tem

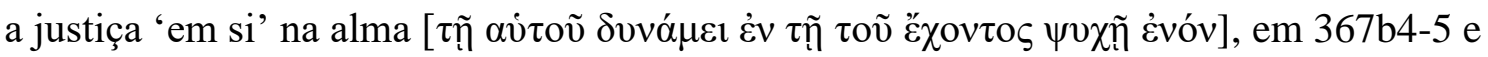

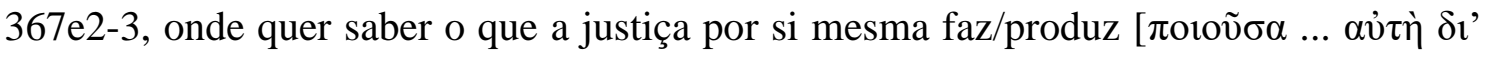
aviๆ́v] e 367d2-3, onde quer ver demonstrado como a justiça por si mesma é útil ao seu

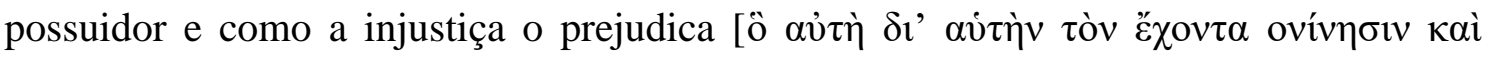

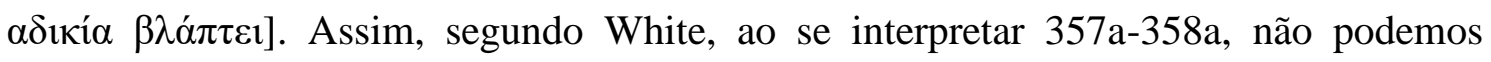
destacá-la do todo de 357a-368b e quando perguntamos o que Platão quer dizer por uma coisa que é boa "por si mesma" não podemos ignorar o fato de que, ao explicá-la, ele está querendo oferecer uma explicação sobre o que a coisa "faz" e assim por diante.

Há também uma razão adicional, que White aponta, com a passagem 357a-358a, para pensar que quando Platão estava construindo sua distinção entre dois caminhos

\footnotetext{
${ }^{43}$ White, op. cit., p. 405.

${ }^{44}$ Ibid., p. 405-6.

${ }^{45}$ Ibid., p. 395-396.
} 
pelos quais uma coisa pode ser boa, há um lado diferente do contraste da noção de alguma coisa que é boa à parte de qualquer coisa que poderia propriamente ser chamada de consequência. Em 357c6-d2, ele mostra seu terceiro tipo de coisas boas, que são tradicionalmente tomadas como sendo coisas boas somente "por suas consequências". No entanto, a terceira classe realmente contém não coisas boas por suas consequências e que podem ser neutras "em si mesmas", mas sim coisas que "por si mesmas" não poderíamos aceitar ou escolher ter, pois estas coisas são explicitamente descritas como penosas (epipona). Se o ponto de Platão é que tais coisas sejam apreciadas "por si mesmas" no sentido moderno, a palavra epipona sugere a dor ou mesmo inconveniente, no que parece de alguma maneira um caminho causal com as coisas em questão. Mas se isto é o que "por si mesmo" significa aqui, não há razão para pensar que quando Platão usa isto das coisas que são boas ou apreciadas por si mesmas, na construção da classificação dos bens, ele deva usar isto para significar "boas por si mesmas" no nosso sentido moderno. Portanto, quando Platão diz que uma coisa pode ser boa "por si mesma" é em razão de alguma coisa que isto "produz/faz", e não temos razão antecedente para dizer que é algo inconsistente em sua terminologia. Por isso, White considera que Platão liga a palavra "fazer" (poiein) com a noção de aitia e aition. ${ }^{46}$

No Fédon o fogo é causa das coisas serem quentes e a neve é a causa delas serem frias. Isto, para White, tem um grande paralelo com a República, quando se afirma que a justiça na alma de alguém o faz feliz ou faz a vida dele prazerosa. ${ }^{47} \mathrm{Nem}$ uma causa nem um efeito têm que ser estabelecidos como sendo uma parte da definição do outro. Se A é a causa de $\mathrm{B}$, há um tipo de conexão necessária não-definicional entre eles. ${ }^{48}$ É importante ressaltarmos aqui que White diz em nota não ter nenhuma resposta filosoficamente adequada para isso que se afirma, e nem um trabalho sobre tudo que Platão disse de relevante sobre isso, sendo ainda necessário uma discussão extensiva de vários aspectos da linguagem de Platão. ${ }^{49}$

Por fim, White irá caracterizar a conexão da justiça e da felicidade como sendo esta: sendo-se justo, no sentido de que cada parte da sua alma faz sua própria função natural e esta única função somente, as partes da alma serão arranjadas de tal maneira

\footnotetext{
${ }^{46}$ Ibid., p. 409-410.

${ }^{47}$ Ibid., p. 411.

${ }^{48}$ Ibid., p. 413.

${ }^{49}$ Ibid., n. 33, p. 413.
} 
que seus desejos e prazeres serão balanceados ou harmonizados da maneira indicada. ${ }^{50}$ Para ele, esta conexão pode ser pensada conforme o padrão que foi posto no Fédon para um certo tipo de causa.

Ao analisarmos a proposta de White, podemos perceber, quanto à maneira de examinar os termos utilizados por Platão, um melhor cuidado para se definir a classificação dos bens. Ao negar a tese moderna de bens por si mesmos e bens por suas consequências, White fortaleceu a tese de se interpretar tais bens se utilizando dos próprios termos platônicos. Pensamos que o autor poderia ter sido mais minucioso em sua análise terminológica, além do exame, por ele feito, sobre a sua maior hipótese: a noção de aitia para conceituar os bens em Platão. Não parece ter ficado claro em seu argumento que possamos nos utilizar da mesma noção utilizado no Fédon para a passagem estudada da República. Aquilo que parece ligar causalmente o bem por si mesmo talvez não possa ser analogamente interpretado com o Fédon se estritamente tomarmos que as palavras aitia ou aition não se encontram na classificação, no entanto, uma noção de causa e efeito ligada ao "em si mesmo" dos bens parece corretamente interpretada.

Segundo Heinaman, para Platão provar que a justiça é superior à injustiça, ele deve provar que a justiça é um bem intrínseco e a injustiça um mal intrínseco. Nisso ele irá apresentar a sua interpretação da divisão dos bens ${ }^{51}$ :

i. Coisas que são boas (a) independentemente de quaisquer consequências que elas possam ter, e/ou são boas (b) porque elas têm um tipo de consequência.

ii. Coisas que são boas tanto por causa de (i) e porque elas têm um segundo outro tipo de consequência além da referida em (i)(b).

iii. Coisas que são boas somente porque elas têm o segundo tipo de consequência - que se especificou em (i)(b).

Para isso, Heinaman irá estabelecer uma distinção entre bem intrínseco, que significa alguma coisa que queremos por si mesma, e bem instrumental, que significa alguma coisa que queremos por suas consequências. Isso envolve outra distinção que ele faz entre a palavra "consequência" utilizada por Platão e a noção contemporânea de uma consequência causal. Um bem intrínseco é alguma coisa que é boa independente do que Platão chama de consequências, no entanto, esse bem intrínseco não é independente

\footnotetext{
${ }^{50}$ Ibid., p. 416.

${ }^{51}$ Heinaman, op. cit., p. 310.
} 
do que chamamos de consequências causais. ${ }^{52}$ Feita esta distinção, ele irá dizer que o terceiro tipo de bem não é por si mesmo um bem, nem é neutro e, dessa forma, deve ser considerado um mal intrínseco ${ }^{53}$, pelos seguintes motivos ${ }^{54}$ :

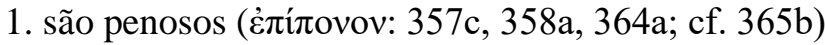

2. são difíceis ( $\chi \alpha \lambda \varepsilon \pi$ óv: 358a, 364a; cf. 364d)

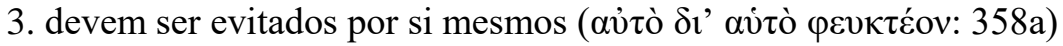

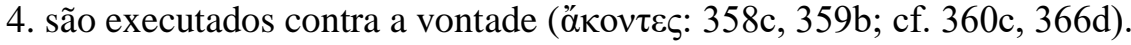

De acordo com Heinaman, não iríamos querer evitar uma coisa neutra, além do que, a utilidade da terceira classe estaria nas suas consequências. Dessa forma, os bens dessa classe seriam apenas bens instrumentais ou, nas palavras dele, eles seriam males intrínsecos. ${ }^{55}$ Para explicitar isto, ele falará do tratamento médico, tomando o remédio como exemplo de um mal positivo, que tomamos pelas suas boas consequências, que superam seu mal intrínseco. ${ }^{56}$

Apesar de não concordarmos com a posição de Heinaman quanto aos bens de terceiro tipo, como iremos deixar claro mais a frente, sabemos que a definição de mal intrínseco é importante para o seu argumento e, por ora, para dar coerência à análise, vamos manter a definição. Dando seguimento, ele irá dividir seis classes de bens e males, sendo estas ${ }^{57}$ :

1. Coisas que são boas por si mesmas e boas por suas consequências

2. Coisas que são boas por si mesmas e têm más consequências

3, Coisas que são boas por si mesmas e não têm boas ou más consequências

4. Coisas que são más por si mesmas e más por suas consequências

5. Coisas que são más por si mesmas e têm boas consequências

6. Coisas que são más por si mesmas e não têm boas ou más consequências.

${ }^{52}$ Ibid., p. 311; e continuará, "em minha interpretação, algumas consequências causais de uma coisa podem ser excluídas das 'consequências' desta coisa e, assim, podem determinar esta como sendo alguma coisa que, por esta razão, é intrinsecamente boa ou má". Heinaman determina em seu trabalho uma distinção terminológica entre os termos: (i) "consequência": que significa o que Platão diz de consequência; e (ii) "consequência causal": que é usada para falar da noção contemporânea de consequência.

${ }^{53}$ Ibid., p. 312.

${ }^{54}$ Ibid., p. 312-3.

${ }^{55}$ Ibid., p. 313. É importante ressaltar que o que Heinaman chama aqui de mal é uma direta

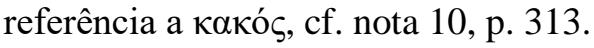

${ }^{56}$ Ibid., p. 313-4.

${ }^{57}$ Ibid., p. 314. 
(1) é a segunda classe de Platão, (3) sua primeira classe e (5) sua terceira classe de bens. Depois disso, Heinaman irá querer provar que as consequências causais de alguma coisa $x$ podem ser relevantes para a sua bondade intrínseca. ${ }^{58} \mathrm{O}$ argumento se baseia em duas declarações ${ }^{59}$ :

(i) Os argumentos de Gláucon e Adimanto em defesa da injustiça pretendem provar que esta é boa por si mesma e, portanto, eles demonstram que tipo de consideração pode ser relevante em estabelecer que alguma coisa é boa por si mesma.

(ii) Os argumentos de Gláucon e Adimanto demonstram que a injustiça é boa por si mesma apelando para as consequências causais da injustiça.

De (1) se afirma que quando no argumento de Gláucon, as consequências da justiça vão para o injusto e as consequências da injustiça vão para o justo, se pode verificar que todas as consequências da justiça são boas e todas as consequências da injustiça são ruins. ${ }^{60}$ Segundo diz, Gláucon e Adimanto têm o intuito de demonstrar que a injustiça é boa, demonstrando que ela é boa por si mesma. ${ }^{61}$ Isso, Gláucon fala em 358d, quando ele diz desejar ouvir Sócrates elogiar a justiça do mesmo modo que ele irá

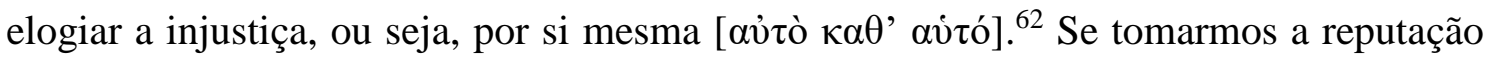
como sendo uma consequência, teremos de admitir, de acordo com a interpretação de Heinaman, que todas as consequências da justiça são boas e todas as consequências da injustiça são ruins. Dessa forma, o motivo para os polloi escolherem a injustiça é que esta é boa por si mesma, segundo pensam.

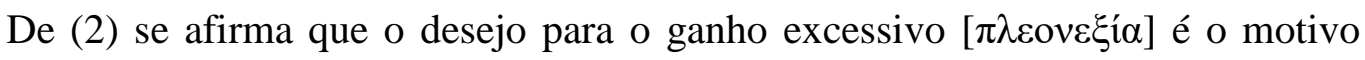
para a ação injusta e isto é visto pelas pessoas como sendo intrinsecamente bom, e o anel de Gyges é utilizado como um exemplo do porque as pessoas pensam assim. ${ }^{63}$ Heinaman considera que na passagem 362b2-c6 há uma distinção entre (i) os benefícios para o completamente injusto que são consequências da justiça (362b2-4), e (ii) os benefícios da injustiça ela mesma (362b4-c6). Por fim, ele retoma Trasímaco na passagem 343d-344a para apontar aquilo que este toma como sendo más consequências

\footnotetext{
${ }^{58}$ Ibid., p. 315-27.

${ }^{59}$ Ibid., p. 315.

${ }^{60}$ Ibid., p. 316.

${ }^{61}$ Ibid., p. 318.

${ }^{62}$ Ibid., p. 318.

${ }^{63}$ Ibid., p. 319-20. Para uma análise do anel de Gyges, ver: Menezes, L.M.B.R. Gyges e a tirania do anel: análise da passagem 359b-362c da República de Platão. Clássica, v.29, p. 7 - 20 , 2016.
} 
causais da justiça por oposição às boas consequências causais da injustiça. De acordo com este pensamento, a injustiça é defendida como um bem intrínseco por causa de suas consequências causais.

Quanto ao outro tipo de consequência utilizado por Platão para indicar aquelas que não são consequências causais, Heinaman diz que irá se preocupar especificamente com aquelas que são as consequências da justiça. ${ }^{64}$ Numerosas são as passagens onde se fala em excluir as consequências da justiça para considerar apenas seu valor intrínseco, sendo estas: 358a, 361b-362c, 362e-363a, 365b, 366d-e, 367b-e, 392b, 392c, 444e445a, 580b-c, 612b-c. Com isso, ele pretende provar a relação entre consequência e reputação nos casos da justiça e da injustiça, pois as consequências causais que se fez menção anteriormente não seguem da reputação de cada uma delas. ${ }^{65}$ Entretanto, Heinaman deve encarar antes uma séria objeção sobre isso: os exemplos de bens de segundo tipo, como sensatez, visão e saúde, e os exemplos de bens de terceiro tipo, como o tratamento médico, têm consequências que não dependem de uma reputação dessas coisas. Se as consequências de x que importam para determinar este valor instrumental não dependem da reputação de x, como pode Platão desejar dizer que as consequências da justiça que importam para determinar seu valor instrumental dependem da reputação de justiça? ${ }^{66}$ Duas são as respostas.

Primeiro, Platão especifica as consequências da justiça que precisam ser excluídas da avaliação do seu valor intrínseco como sendo as recompensas que seguem a reputação da justiça. ${ }^{67}$ Segundo, ao considerarmos a passagem $367 \mathrm{c}-\mathrm{d}^{68}$, Heinaman supõe que a saúde, a visão e a sensatez não têm consequências que seguem das suas reputações, mas quando se retorna para a justiça, as consequências da justiça são novamente atribuídas à reputação da justiça. Nesta interpretação de 367c-d, o fato de que 357c mencione exemplos de bens cujo valor instrumental nada tem com a reputação não pode demonstrar que o valor instrumental da justiça não dependa da reputação da justiça.

Apesar de ele pensar as consequências causais de $\mathrm{x}$ como possivelmente relevantes para avaliar o valor intrínseco de x, ele admite que talvez isso não aconteça

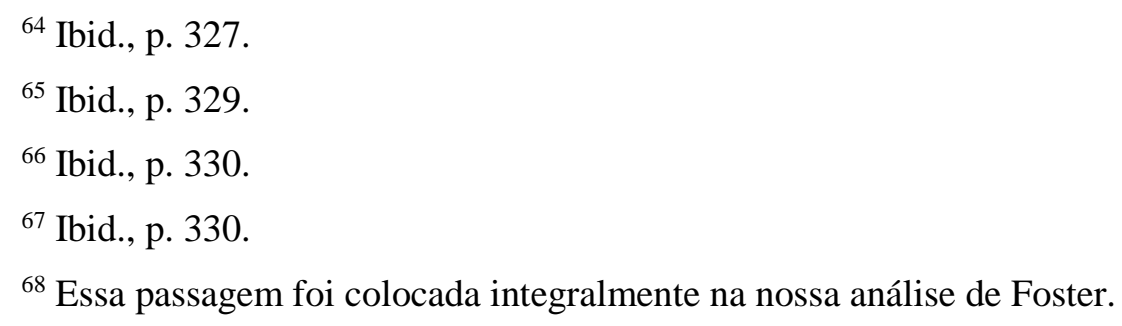


em todos os casos. Considerando-se o ponto de vista dos muitos que tomam a justiça como difícil e penosa e a colocando no terceiro tipo de bem, é possível supor dor e prazer como consequências causais de uma ação injusta, embora Heinaman não considere que Platão pense a dor como um mal intrínseco somente por suas consequências causais, o que o faz supor que o fato de x ser mal por si mesmo não seja determinado somente pelas suas consequências causais. ${ }^{69}$

Segundo ele, nem todas as consequências de $\mathrm{x}$, que fazem dele um bem instrumental, seguem de x. Este necessita não ser uma condição suficiente destas consequências e isto evidentemente se aplica às consequências da justiça e da injustiça. Y ser uma consequência de $\mathrm{x}$ implica que y usualmente segue $\mathrm{x}$, e o mesmo, diz-nos ele, se aplicaria às consequências causais. Como exemplo, fala que a ação injusta levar ao acúmulo de riqueza ser uma das razões para a injustiça ser boa por si mesma nos discursos de Gláucon e Adimanto, embora não haja razão para Platão acreditar que isto necessariamente segue, mesmo quando a ação injusta é empreendida para obter dinheiro. Nem é x ele mesmo uma condição necessária para as consequências de x. As consequências de $\mathrm{x}$ podem seguir de alguma maneira outro que $\mathrm{x}$, como no exemplo de Gláucon em que o completamente injusto obtém as consequências da justiça que seguem da aparência da justiça. Assim, x não é uma condição necessária para as consequências de $x$ que fazem $x$ bom por si mesmo e por suas consequências. ${ }^{70}$ Heinaman irá concluir dizendo que a noção de bem e de mal intrínsecos são relativos a alguém afetado pelo item em questão, levando em consideração se a pessoa é agente ou paciente do bem em questão. Isso o faz pensar que diferentes tipos de consequência causal são relevantes para determinar se a ação é um bem intrínseco. ${ }^{71}$

O trabalho de Heinaman apresenta alguns problemas que pretendemos agora discutir. Primeiramente devemos atentar para a interpretação dos bens de terceiro tipo feita por ele. Não nos parece que o fato de algo ser penoso e difícil ser suficiente para caracterizá-lo como um mal, além do mais, os bens de terceiro tipo não são úteis por suas consequências, como ele pensa, mas são por si mesmos. ${ }^{72}$ De qualquer maneira,

\footnotetext{
${ }^{69}$ Heinaman, op. cit., p. 331-2.

${ }^{70}$ Ibid., p. 333.

${ }^{71}$ Ibid., p. 334-5.

${ }^{72}$ Como será melhor desenvolvido mais à frente em nosso trabalho.
} 
um bem não pode ser gerado de um mal, conforme podemos observar a relação entre mal e prejuízo; bem e utilidade no diálogo de Sócrates e Adimanto colocado a seguir:

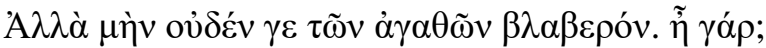

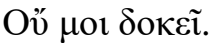

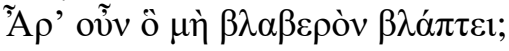

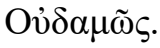

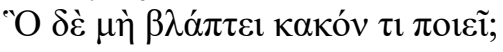

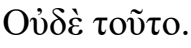

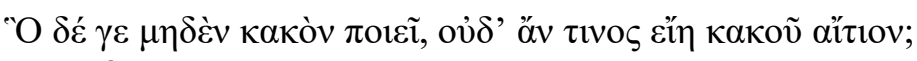

Пడ̃ $\gamma \alpha \dot{\alpha} \rho$

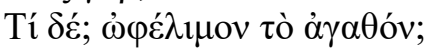

Naí.

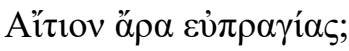

Naí.

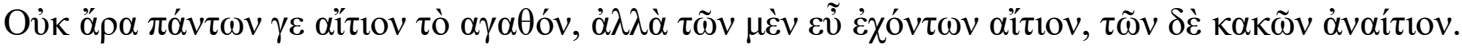

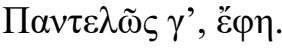

- Mas nada que seja bom é prejudicial, pois não?

- Não me parece que seja.

- Ora o que não é prejudicial é nocivo?

- De modo algum.

- Mas o que não é prejudicial faz algum mal?

- Também não.

- E aquilo que não faz mal algum não poderia ser causa de nenhum mal?

- Como havia de sê-lo?

- Mas então o que é bom não é útil?

- É.

- Ora então o bem não é a causa de tudo, mas causa de bens e sem culpa nos males.

- Com toda a certeza. ${ }^{73}$

Dessa passagem podemos concluir que: primeiro, o bem não é prejudicial, segundo, o que é prejudicial é nocivo, terceiro, o que não é prejudicial não faz mal, quarto, o que não faz mal não pode ser causa do mal, quinto, o que é bom é útil e causa de benefício, sexto, o bem não é causa de males. Platão parece estar estabelecendo uma

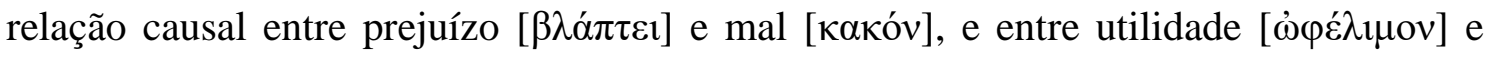
bem [ảy $\alpha \theta$ óv]. Se o bem só é causa de bens e não pode ser causa de males, podemos também pensar que: primeiro, o que é prejudicial não é útil, segundo, o prejudicial não é bom, terceiro, o prejudicial faz mal, quarto, o mal não é útil e, portanto, não pode ser causa de bens. Concluímos, desse modo, que não existe relação causal possível entre males e bens. Portanto, esses bens de terceiro tipo são evitados e executados contra a vontade, por serem penosos e difíceis, apesar de continuarem sendo úteis por si mesmos, e nada que é útil é intrinsecamente mal.

\footnotetext{
${ }^{73}$ Rep., 379b3-16. As modificações na tradução são nossas.
} 
Quanto ao exemplo do remédio ele pode ser refutado de duas maneiras. A primeira é usando os próprios termos de Heinaman, se o remédio é um mal que ao ser tomado produz um bem, esse bem é uma consequência causal de se tomar o remédio e não apenas uma consequência que possa ser dele retirável. Assim, se o bem produzido é uma consequência causal, tomar um remédio deve, nos próprios termos de Heinaman, ser um bem intrínseco. A segunda maneira diz respeito à total desconstrução da divisão em seis tipos de bens e males do autor. Com base na interpretação da passagem 379b316 acima exposta, podemos dizer que um bem não pode ter como consequência um mal e vice-versa. Dessa maneira, os únicos sobreviventes de sua divisão seriam (1) e (3), pois são bens por si mesmos que não têm males como consequências, e (4) e (6), pois são males por si mesmos que não têm bens como consequências. Isso não permite que o exemplo do remédio se encaixe no termo (5) como pretendia Heinaman, pois não há mal que cause bens.

Um segundo ponto do trabalho de Heinaman que devemos verificar é sua interpretação das consequências de Platão. Se pensarmos que existem bens que têm consequências desejadas, mas essas não derivam de sua reputação e nem são consideradas por seus misthoi, então essas consequências são na verdade consequências causais que não podem ser separadas desses bens e, portanto, de acordo com a terminologia de Heinaman, deveriam fazer parte do 'por si mesmo' do bem, não podendo ser chamadas de consequência nos termos de Platão. Quando ele diz que "y ser uma consequência de $\mathrm{x}$ implica que $\mathrm{y}$ usualmente segue $\mathrm{x}$ "74, e que isso também se aplica às consequências causais, ele está simplesmente desconstruindo todo o trabalho que ele teve para estabelecer uma distinção entre consequências. $\mathrm{O}$ exemplo dado por ele, da ação injusta levar ao acúmulo de riqueza não ser algo necessário, faz automaticamente com que este exemplo deixe de ser uma consequência causal. Uma consequência causal sempre segue de x e não apenas "usualmente" como coloca Heinaman.

Por fim, o relativismo ${ }^{75}$ posto pelo autor no final de seu trabalho é por demais absurdo. Ele não só em nada contribui para o problema dos bens, como acaba com todo o desenvolvimento da questão. Não haveria motivo para Sócrates defender a justiça como sendo boa por si mesma se o que conta é o ponto de vista entre agente e paciente.

\footnotetext{
${ }^{74}$ Heinaman, op. cit., p. 333.

${ }^{75}$ Ibid., p. 333-334.
} 
Provar que alguma coisa é um bem por si mesmo não significa elogiar este de forma parcial, mas sim analisá-lo de maneira integral, independente se este é visto pelo agente ou pelo paciente do bem. Se algo pode ser bom ou ruim dependendo do ponto de vista, torna-se irrelevante a classificação deste algo.

De acordo com Payne, Platão distingue bens que são atividades constituintes das erga e bens que são atividades que produzem erga como resultados separados. ${ }^{76}$ Entendendo isso, o autor pretende explicar a colocação de Sócrates da justiça como sendo um bem de segundo tipo através da seguinte separação: (i) benefícios criteriais da justiça - envolveria consequências benéficas de ser justo; (ii) benefícios adicionais da justiça - envolveria consequências benéficas da justiça. ${ }^{77}$ Para ele, o cerne para que possamos entender a divisão dos bens propostos por Gláucon é identificar a diferença existente entre a segunda classe de bens e a terceira classe de bens. segundo o Desafio de Gláucon, ele deveria provar que a justiça traz benefícios ao homem justo independente de qualquer misthos, o que também inclui o "não ser governado por alguém pior'. Segundo Payne, "Este ganho particular não é um benefício adicional no sentido estrito introduzido acima porque este ganho que é produzido para uma determinada atividade não é independente da excelência exibida na performance da atividade de governar". ${ }^{78}$ Dessa forma, o misthos de "não ser governado por alguém pior' não deveria ser entendido como os demais misthoi de um bem de terceiro tipo, pois ele é inerente à escolha do bom governante e não pode ser adicionado caso o bom governante não opte por governar ou retirado caso opte por governar. Apesar de concordarmos com a pertinência da observação de Payne, entendemos que o desafio de Gláucon para Sócrates exige a ausência de qualquer misthos na resposta antes da defesa da justiça por si mesma. O que estamos dizendo é que embora o misthos esteja presente em um bem de segundo tipo, a resposta não pode se reduzir ao misthos, pois a justiça deve ser provada antes de tudo como boa em si mesma. Dessa maneira, mesmo se tomarmos este tipo específico de misthos como inerentes da escolha do bom governante em governar, é claro que não é este o tipo de resposta que Gláucon espera de um elogio da justiça em si mesma.

\footnotetext{
${ }^{76}$ Payne, op. cit., p. 65.

${ }^{77}$ Ibid., p. 60.

${ }^{78}$ Payne, A. The Division of Goods and Praising Justice for itself in Republic II. Phronesis, v. 56, 2011, p. 68, nota 13 .
} 


\section{Classificação dos bens: uma nova interpretação}

Apresentadas as análises dos principais intérpretes do problema da classificação dos bens na República, passemos para a nossa própria interpretação. Antes de tudo, queremos dizer que concordamos com o grupo que diz que é necessário entender o que Platão quer dizer com 'bem por si mesmo' e 'bem por suas consequências' em seus próprios termos e não nos termos da interpretação moderna, pois o que parece estar em jogo é a implicação destes bens de acordo com o prazer que proporcionam, tendo cada um deles uma dynamis que lhe é peculiar e que produz um efeito na alma daquele que os recebe. Concordamos com Kirwan que há uma diferenciação entre bens agradáveis e bens penosos, compreendendo que o primeiro tipo de bem é agradável, o terceiro tipo de bem é penoso, mas útil e o segundo tipo de bem é agradável e útil. Para Sócrates provar que a justiça é boa por si mesma, ele deve provar que a justiça é agradável e útil. Se a felicidade for consequência da justiça, então ela será um bem penoso, ou seja, de terceiro tipo. Assim como também aceitamos a visão de Sachs, que indica que o desafio

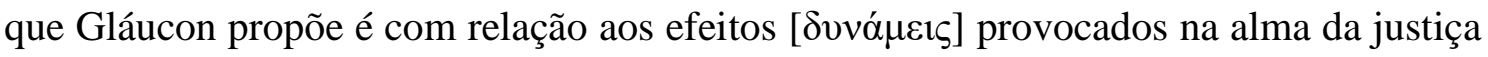
e da injustiça, e que tais efeitos são fundamentais para se compreender o desafio como um todo. Para melhor explicarmos isto, iremos examinar os termos de Platão para se referir à sua divisão dos bens, provando assim que o uso feito por Platão destes é consistente. Para tal colocamos a passagem inteira dos bens no original grego.

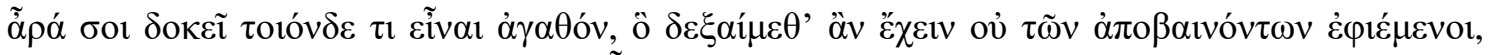

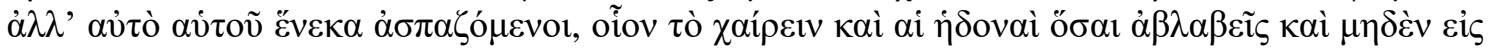

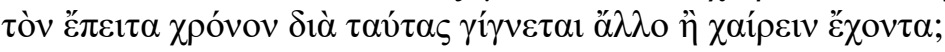

$[\ldots]$

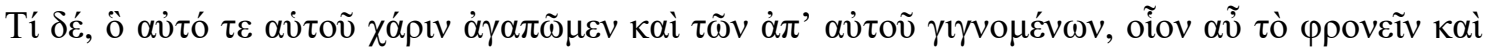

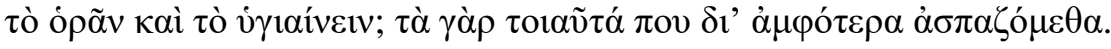

$[\ldots]$

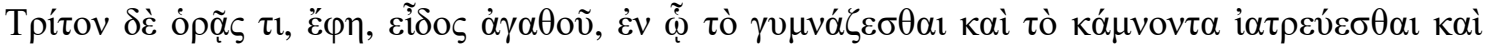

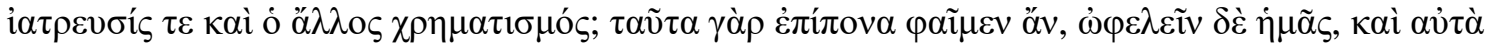

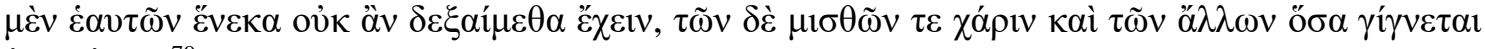
$\dot{\alpha} \pi^{\prime} \alpha \hat{\tau} \tau \tilde{\omega}{ }^{79}$

Ao analisarmos a passagem, podemos notar o uso de termos próximos entre as definições de cada bem que podem ser a chave para identificar a classificação como um todo. Comecemos por aquilo que é comumente traduzido por 'consequência'. A

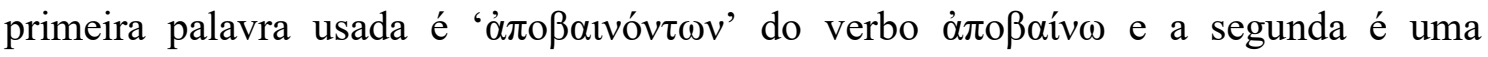

\footnotetext{
${ }^{79}$ Rep. 357b4-d2.
} 


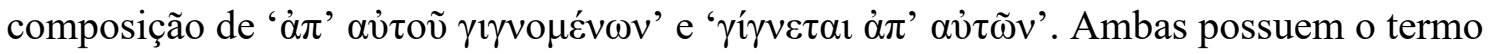
‘ả̇ó', e por isso, este será o primeiro a ser examinado. De acordo com Chantraine, à $\pi$ ó tem sentido de: “'longe de, separado de' diferente de غ̇к 'fora de' [...] tem um grande lugar em composição para exprimir a ideia de 'afastar/remover; descartar/separar', cf.

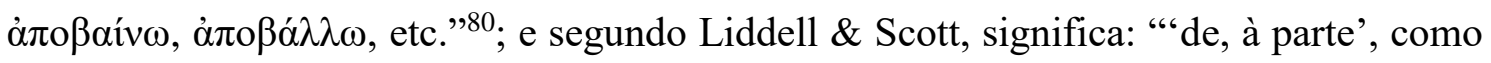

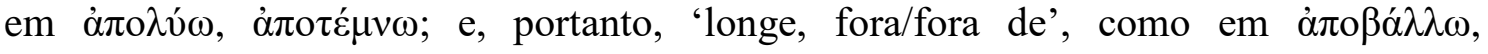

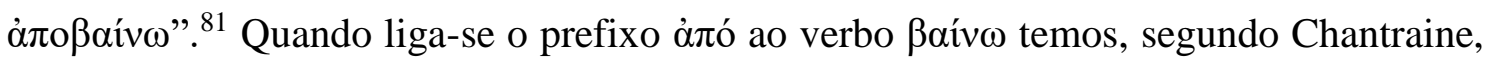

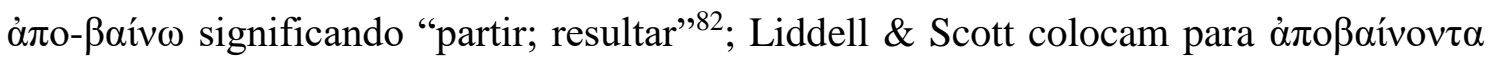
com o significado de "os resultados". ${ }^{83}$ O verbo ḋ circunstâncias, um sentido de fora, separado e removido. Como afirma White em seu trabalho, "a palavra não é, particularmente em seu uso absoluto sem preposição e substantivo, uma palavra regular grega para 'consequências', 'efeitos' ou 'resultados", ${ }^{84} \mathrm{O}$ termo não poderia expressar por si próprio uma conexão causal,

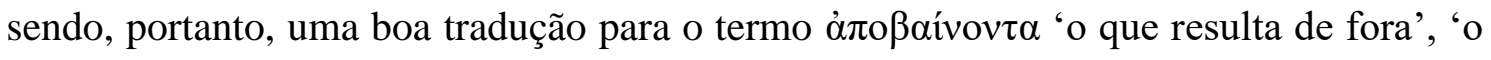

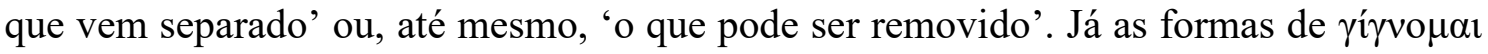

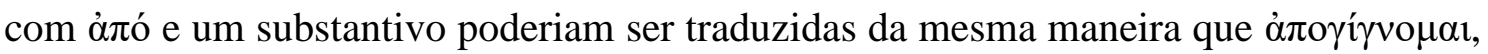
que pode significar estar longe; não ter parte em; ser tirado/retirado; ausente; desaparecer; partir/afastar ${ }^{85}$, contrário ao verbo $\pi \rho \circ \gamma^{\prime} \gamma v o \mu \alpha \iota$, que significa vir de;

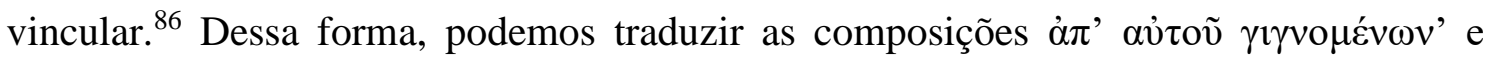

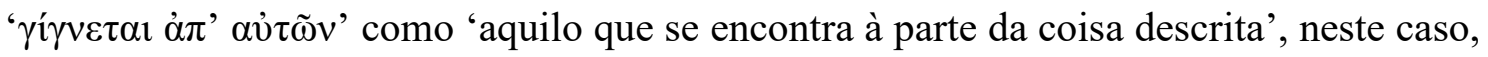
os bens em questão.

Quanto ao que se diz 'por si mesmo' ou 'em si mesmo' temos os termos 'aủ ò

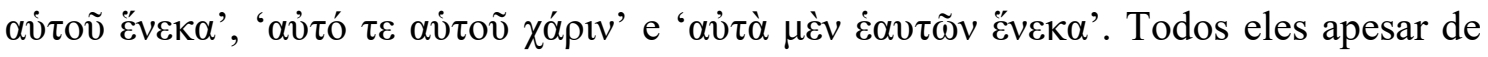
poderem significar alguma coisa por si mesma devem ser observados com o contexto em que se encontram para não haver erros de interpretação. Os bens de primeiro tipo

\footnotetext{
${ }^{80}$ Chantraine, P. Dictionnaire Étymologique de La Langue Grecque. Histoire de Mots, tome I. Paris: Éditions Klincksieck, 1968, p. 111.

${ }^{81}$ Liddell, H. G.; Scott, R. Greek-English Lexicon (2 ed.). New York: Harper \& Brothers, 1883, p. 175.

${ }^{82}$ Chantraine, op. cit., p. 170.

${ }^{83}$ Liddell, H. G.; Scott, R., op. cit., p. 175.

${ }^{84}$ White, op. cit., p. 418.

${ }^{85}$ Liddell, H. G.; Scott, R., op. cit., p. 177.

${ }^{86}$ Ibid., p. 1304.
} 


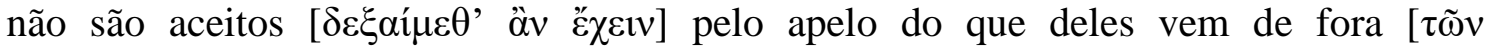

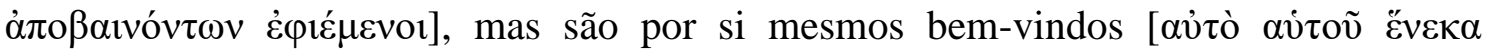

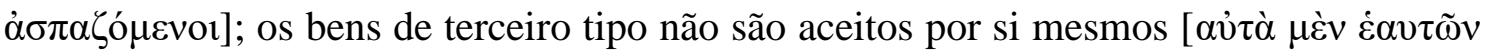

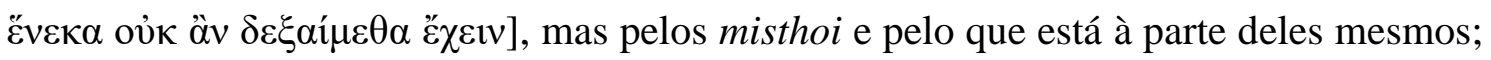

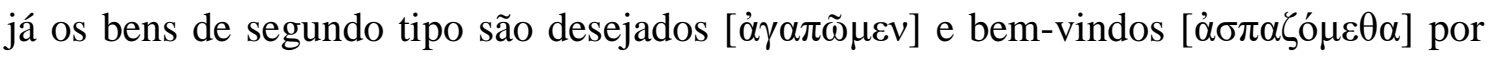
ambos os motivos. Parece-nos que todos eles estão ligados ao prazer que os bens proporcionam. Os bens de primeiro tipo são aqueles que nada mais no tempo é

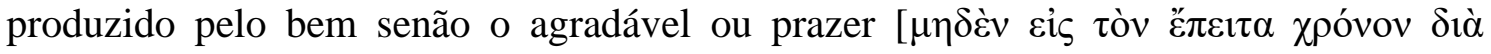

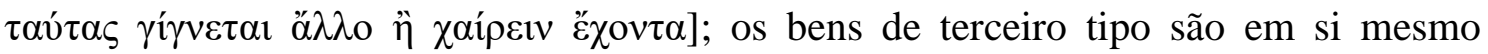
epipona e úteis; e os bens de segundo tipo, por serem de ambas as formas desejados, são agradáveis e úteis. Antes de finalizar o assunto, queremos aqui atentar para a utilidade

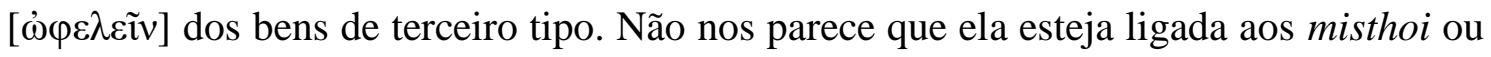
qualquer tipo de coisa à parte do bem em questão que não seja ele mesmo. Baseamo-

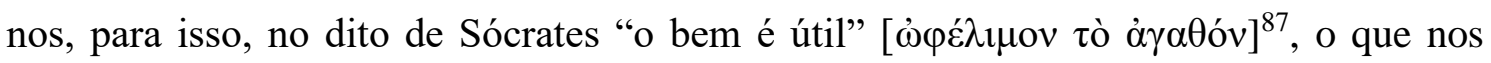
parece indicar a utilidade do bem por si mesmo independente do que possa advir à parte dele. A ginástica e o tratamento médico, por exemplo, apesar de penosos, parecem ser úteis, independente dos misthoi que possam vir de sua prática. Podemos reforçar ainda mais este argumento se lembrarmos no Livro I o seguinte diálogo entre Sócrates e Trasímaco:

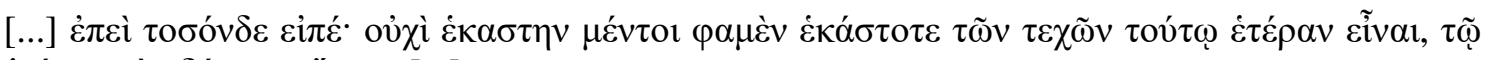

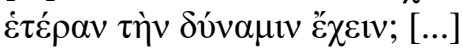

A $\lambda \lambda \alpha \grave{\alpha} \tau o v ́ \tau \omega, \ddot{\varepsilon} \varphi \eta, \dot{\varepsilon} \tau \dot{\varepsilon} \rho \alpha$.

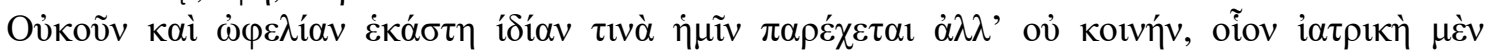

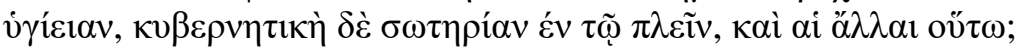

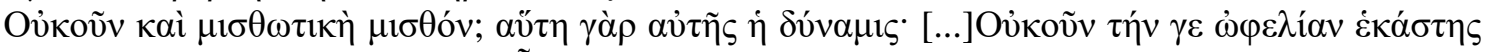

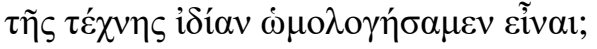

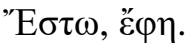

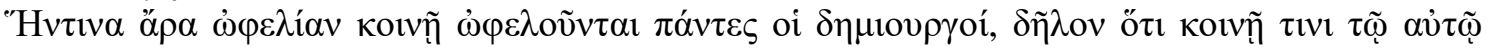

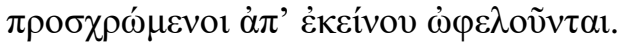

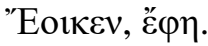

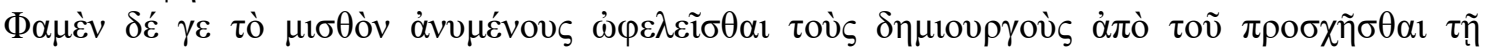

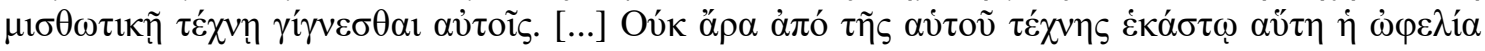

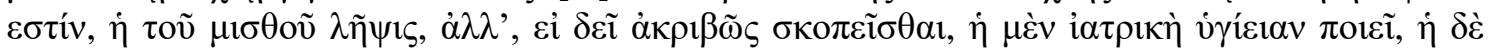

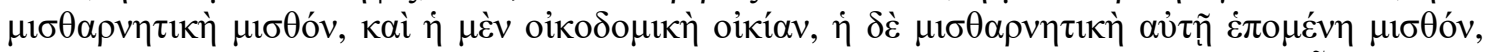

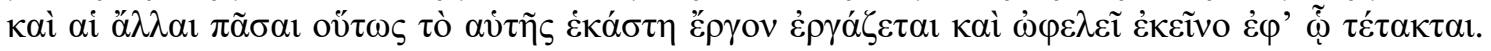

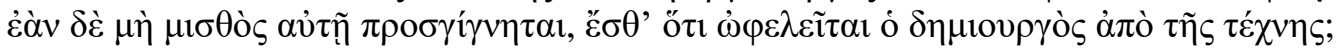

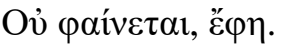

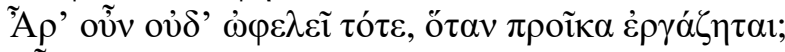

Oĩนal है $\gamma \omega \gamma \varepsilon$.

${ }^{87}$ Rep., $379 \mathrm{~b} 11$. 
- [...]diz-me: não afirmamos nós sempre que cada uma das artes se diferencia das outras pelo fato de ter uma potência específica? [...]

- Diferenciam-se por isso, sim.

- E não é verdade que cada uma das artes nos proporciona qualquer utilidade específica, e não comum, como a da medicina, a saúde, a do piloto, a segurança de navegação, e assim por diante?

- Exatamente.

- Portanto, também a arte dos lucros tem o seu salário? Pois é esse o efeito que lhe é peculiar.

[...] Acaso não concordamos que há uma utilidade peculiar a cada arte?

- Seja.

- Se há uma utilidade de que gozam todos os artífices em comum, é manifesto que devem empregar alguma faculdade adicional, comum a todos, e daí derivarem a utilidade.

- Assim parece.

- Ora, nós afirmamos que a utilidade dos artífices, quando ganham um salário, lhes advém de empregarem uma faculdade adicional à arte dos lucros. [...] Por conseguinte, não é da sua própria arte que advém a cada um esta utilidade, que é a obtenção de um salário; mas devemos examinar a questão com rigor: a medicina produz a saúde, a arte dos lucros, o salário, e a do arquiteto, uma casa; ao passo que a arte dos lucros, que a acompanha, dá o salário. E as outras todas, igualmente, produz cada uma o seu efeito e são úteis àquele a quem se aplicam. Se, porém, não se lhe juntar um salário, é possível o artífice auferir alguma utilidade da sua arte?

- Não me parece.

- Mas acaso ele não é útil, quando trabalha de graça?

- Com certeza, assim o creio. ${ }^{88}$

Apesar dos misthoi serem úteis àquele que exerce sua arte, é inegável que o exercício da sua arte continua sendo útil para outros, mesmo que o artífice não receba nada por isto. Da mesma maneira, percebemos que os bens de terceiro tipo são penosos e úteis por si mesmos, pois mesmo que nenhum misthos venha com esse bem, ele continua tendo a sua utilidade. Podemos dizer, assim, que os misthoi e a ophelia são referentes a pessoas diferentes, um é o que pratica o bem e recebe o misthoi por sua prática, e o outro aquele que recebe a ophelia própria do bem em questão.

Dessa forma, a divisão dos bens, segundo a nossa interpretação, assim ficaria:

(i) Bens de primeiro tipo são aqueles que não são aceitos pelo que resulta de fora de si próprio, mas que por si mesmos são bem-vindos e úteis, e nada mais no tempo é produzido por eles senão o agradável.

(ii) Bens de segundo tipo são aqueles que são desejados e bem-vindos tanto por si mesmos, por serem agradáveis e úteis, como pelo que segue à parte deles mesmos.

(iii) Bens de terceiro tipo são aqueles que não são aceitos por si mesmos por serem penosos, apesar de serem úteis. Estes bens são aceitos somente pelas recompensas e por outras coisas que seguem à parte deles mesmos.

Feita esta definição sobre os bens, gostaríamos de esclarecer alguns detalhes. Parece-nos importante para a classificação entender que aquilo que usualmente é chamado de 'consequências' pelos estudiosos dessa passagem não pode ser causalmente

\footnotetext{
${ }^{88}$ Rep., 346a1-e2. Grifos e modificações na tradução são nossos.
} 
ligado aos bens, pois estas 'consequências' podem ser deles retiradas, mesmo que seja numa suposição argumentativa, como é o caso que Gláucon propõe colocar a aparência da justiça para o completamente injusto e a aparência da injustiça para o completamente justo. Quando dizemos que estas resultam de fora ou seguem à parte do próprio bem em questão significa dizer que o que determina a relação delas com o bem não é o em si mesmo deste bem, mas que, apesar de possuírem uma ligação com o bem, tal relação não é uma consequência causal, mas uma resultante que se encontra fora do 'por si mesmo'. Sendo assim, a justiça é colocada, segundo o parecer dos polloi, no terceiro tipo de bem, que é

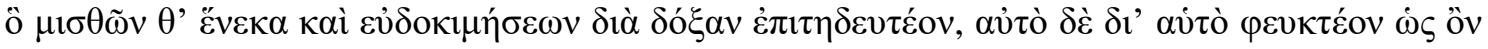

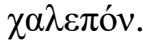

aquele que se pratica por causa da aparência, em vista das recompensas e da reputação, mas que por si mesmo se deve evitar, como sendo dificultoso. ${ }^{89}$

A crença e a atitude das pessoas com relação ao bem parecem influir diretamente na doxa que se tem deste bem e sobre os misthoi que se adquire devido a esta doxa. Dessa forma, o que faz com que a justiça possua uma boa reputação, honrarias e recompensas é a maneira como ela é vista pelos outros devido ao que ela tem de útil por si mesma. Por isso, de acordo com a visão dos polloi, a justiça faz parte do terceiro tipo de bem, aquele que é penoso e útil por si mesmo, além de possuir uma doxa que concede misthoi. Sócrates em resposta a estes, irá dizer

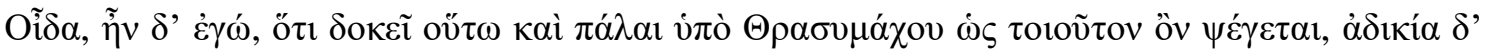

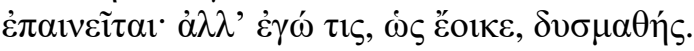

Eu sei que é esse o seu parecer, e há muito que Trasímaco censura a justiça por esse motivo, e elogia a injustiça. Mas eu sou duro de entendimento, ao que parece. ${ }^{90}$

Sócrates parece querer indicar que tanto Trasímaco como os polloi têm a mesma visão da justiça, fazendo ela parte dos bens de terceiro tipo, aqueles que se praticam em vista da doxa. Mas a injustiça é colocada em outro lugar por eles. Segundo Trasímaco,

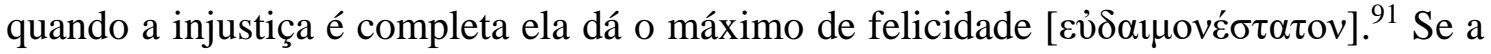
injustiça é desejada pela maioria das pessoas como um bem, não pode ser por sua própria doxa, pois no caso da injustiça esta doxa é ruim, mas pela maneira como o

\footnotetext{
${ }^{89}$ Rep., 358a5-6.

${ }^{90}$ Rep., 358a7-9.

${ }^{91}$ Rep., 344a.
} 
injusto lida com a doxa da injustiça para alcançar o seu objetivo final. Dessa forma, a injustiça aparece como produtora de felicidade para aqueles que a praticam, se constituindo, na verdade, como um jogo de aparências, mas sem que possamos tomá-la pela sua essência.

Antes de prosseguirmos queremos chamar atenção para um problema importante sobre a interpretação que fazemos do que 'resulta à parte' do bem como sendo característicos da doxa. ${ }^{92}$ Os exemplos de bens de segundo tipo, como sensatez, visão e saúde, e os exemplos de bens de terceiro tipo, como o tratamento médico, não têm algo à parte que resulta da doxa. Nesse ponto, aceitamos a resolução de Heinaman para o problema, mas gostaríamos ainda de acrescentar uma reinterpretação nossa da passagem 358a aqui utilizada. Entendemos que nem todos os bens de segundo tipo têm doxa, assim como é possível que existam bens de terceiro tipo nessa mesma situação. Portanto, a doxa aqui colocada deve ser lida num sentido mais brando do termo, podendo ser interpretada da seguinte maneira: o bem de terceiro tipo é aquele que se pratica por causa da aparência (doxa), se este assim a tiver, e em vista das recompensas e/ou da reputação, mas que por si mesmo se deve evitar, como sendo dificultoso. Dessa maneira, poderíamos compatibilizar todos os bens dentro da classificação e dizer que somente aqueles que possuírem doxa podem ter suas consequências retiradas. A justiça, portanto, seria censurada pelos polloi por só produzir misthoi pela doxa, ao contrário, da injustiça que seria elogiada por conseguir bens que não são fornecidos pela própria doxa.

Quanto ao 'por si mesmo' do bem, é entendido como uma relação causal do bem tanto com o prazer que ele proporciona como com a sua utilidade. No caso da justiça, ela seria vista pelos polloi como penosa e, portanto, deve ser evitada, mas possui sua utilidade, o que faz com que os mesmos polloi atribuam à justiça uma boa reputação para aqueles que a seguem, além de honrarias e recompensas. Assim, os bens de primeiro tipo são aqueles que são desejados pelo agrado que transmitem e também são úteis por isso; os bens de segundo tipo são aqueles que são desejados pelo que é agradável e útil, além do que vem à parte deles; e os bens de terceiro tipo são aqueles que não são desejados por serem penosos, mas têm utilidade e são desejados pelo que vem à parte deles.

${ }^{92}$ Cf. Foster, 1937, p. 387; Kirwan, 1965, p. 165-6; Irwin, 1999, p. 166-7; Heinaman, 2002, p. 329-31. 
Nossa interpretação não nega que os bens de terceiro tipo "são bens que não queremos ter pelo que eles são", pois, como foi dito, são bens penosos. Mas ser um bem penoso não nega a sua utilidade em si. A justiça para os polloi é penosa, mas útil por impedir que os homens cometam injustiças. Os misthoi são referentes às honras, aparência e riquezas. Se a utilidade dos bens de terceiro tipo fosse um misthos, poderia ser retirada do bem como qualquer outro misthos pode ser retirado, pois os misthoi não produzem benefícios causais. Dessa forma, dizer que algo é útil por si mesmo não

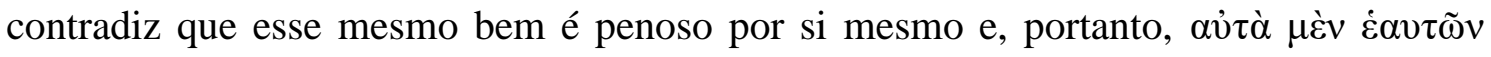

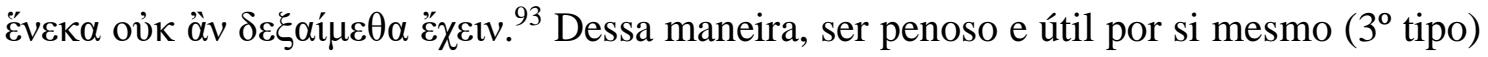
é diferente de ser agradável e útil por si mesmo ( $2^{\circ}$ tipo).

Há, portanto, um óbvio contraste entre a posição de Sócrates e a da maioria (polloi) quanto à justiça. Segundo aquele, a justiça é desejada tanto em si mesma, por ser agradável e útil, quanto por suas consequências; já estes pensam ser a justiça penosa e útil, sendo desejada apenas por suas consequências, isto é, suas recompensas (misthoi) e sua aparência (doxa). Como ambos aceitam que a justiça tem consequências, Gláucon

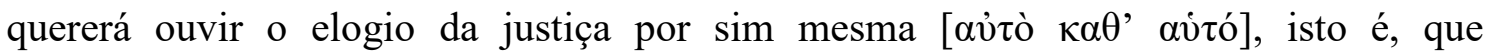
capacidade (dynamis) ela possui por si mesma na alma do homem justo sem levar em conta as consequências decorrentes dela. ${ }^{94}$ Para expor como Gláucon quer ouvir o seu desafio respondido, ele irá dividir o seu discurso em três argumentos. ${ }^{95}$

O desafio de Gláucon, atrelado a essa interpretação da divisão dos bens, fica nos seguintes termos: ele deseja ouvir de Sócrates qual é a dýnamis por si mesma da justiça e da injustiça quando cada uma destas existe na alma, demonstrando se estas transmitem uma pena ou um prazer, assim como, se são úteis ou prejudiciais à alma que habitam, sem dar relevância a nenhum tipo de recompensa ou a outras boas coisas que resultam à parte da própria dynamis da justiça e da injustiça.

Luiz Maurício Bentim da Rocha Menezes

Instituto Federal do Triângulo Mineiro

\footnotetext{
${ }^{93}$ Rep., 357c9.

${ }^{94}$ Rep., 358b4-7.

${ }^{95}$ Para uma exposição e análise dos argumentos de Gláucon, ver: Menezes, 2014 e 2017.
} 


\section{Bibliografia}

Adam, J. (1979) The Republic of Plato. Edição de J. Adam. Cambridge: Cambridge University Press, 2v.

Annas, J. (1981) An Introduction to Plato's Republic. Oxford: Oxford University Press.

Chantraine, P.(1968-80) Dictionnaire Étymologique de La Langue Grecque. Histoire de Mots, tomes I-IV. Paris: Éditions Klincksieck.

Cross, R. C.; Woozley, A. D. (1994) Plato's Republic: A Philosophical Commentary. London: Macmillan, 1994 (1964 - 1 ed.).

Foster, M. B. (1937) A Mistake of Plato's in the Republic. Mind, v. 46, n. 183, p. 386-393.

Foster, M. B. (1938) Mistake of Plato's in the Republic: A Rejoinder to Mr. Mabbott. Mind, v. 47 , n. 186, p. 226-232.

Gilboa, D. (1996) Glaucon's challenge challenged. Hermathena, v. 160, p. 9-22.

Heinaman, R. (2002) Plato's Division of Goods in the Republic. Phronesis, v. 47, n. 4, p. 309335.

Irwin, T. H. (1999) Republic 2: Questions about Justice. In: Fine, Gail. Plato 2. New York; Oxford: Oxford University Press, p. 164-185.

Kirwan, C. (1965) Glaucon's Challenge. Phronesis, v. 10, n. 2, p. 162-173.

Liddell, H. G.; Scott, R. (1883) Greek-English Lexicon (2 ed.). New York: Harper \& Brothers.

Mabbott, J. D. (1937) Is Plato's Republic Utilitarian?, Mind, v. 46, n. 184, p. 468-474.

Menezes, L. M. B. R. (2016) Gyges e a tirania do anel: análise da passagem 359b-362c da República de Platão. Clássica, v.29, p. 7-20.

Menezes, L. M. B. R. (2017) O Contrato De Gláucon. Transformação, v. 40, p.235-252.

Menezes, L. M. B. R. (2014) O lógos dos polloí no argumento de Gláucon. Filosofia Unisinos, v. 15, p.01-19.

Payne, A. (2011) The Division of Goods and Praising Justice for itself in Republic II. Phronesis, v. 56, p. 58-78.

Pereira, M. H. R. (2001) A República. Tradução de Maria Helena da Rocha Pereira. 9. ${ }^{a}$ ed. Lisboa: Fundação Calouste Gulbenkian.

Reeve, C. D. C. (2008) Glaucon's Challenge and Thrasymacheanism. Oxford Studies in Ancient Philosophy, v. 34, p. 69-103.

Reeve, C. D. C. (2006) Philosopher-Kings. The Argument of Plato's Republic. Indianópolis; Cambridge: Hackett Publishing Company.

Sachs, D. (1978) A Fallacy in Plato's Republic. PhR, v. 72, n. 2, p. 141-158, 1963, reimpresso in Vlastos, G. (ed.), Plato 2. Notre Dame, Indiana: University of Notre Dame Press, p. 35-51.

Slings, S. R. (2003) Platonis Rempvblicam, recognovit brevique adnotatione critica instrvxit: S. R. Slings. Oxford: Oxford University Press.

White, N. (1984) The Classification of Goods in Plato's Republic. JHPh., v. 22, n. 4, p. 393421. 